\title{
The Role of Investment Banking in M\&A Operations: Empiric Pre and Post Lehman Evidence
}

\author{
Vincenzo Capizzi \\ Full Professor of Banking and Finance, Ph.D. \\ Department of Economics and Business Studies \\ Eastern Piedmont State University, Novara, Italy \\ SDA Bocconi School of Management, Milan, Italy \\ Tel: 39-032-137-5438_ E-mail: vincenzo.capizzi@eco.unipmn.it \\ Renato Giovannini (Corresponding author) \\ Full Professor of Banking and Finance, Ph.D. \\ Department of Economics and Management \\ Guglielmo Marconi University, Rome, Italy \\ SDA BOCCONI School of Management, Milan, Italy \\ Tel: 39-064-890-5707_Ｅmail: r.giovannini@unimarconi.it
}

Received: September 17, 2014 Accepted: October 29, 2014 Published: December 2, 2014

doi:10.5296/ifb.v1i2.6638

URL: http://dx.doi.org/10.5296/ifb.v1i2.6638

\begin{abstract}
The role of investment banks in M\&A operations is analyzed on the basis of empiric evidence. In particular, to point out the variations in the impact of the certification effect which can be ascribed to investment banks, the relationship between the value created for the shareholders in companies involved in special underwriting operations and the reputation of the banks appointed to act as advisors is examined. The analysis, which uses an original measuring system in order to assess and classify the reputation variable, focuses on transactions that have taken place between listed companies in two time frames, symmetrical to each other, specifically pre and post the Lehman Brothers bankruptcy. The total sample is composed of 229 transactions, divided into 161 and 68 observations, respectively pre and post Lehman. The result is that in the post Lehman period, unlike the preceding time firame, for which no
\end{abstract}




\section{Macrothink}

significant empiric evidence is found, the wealth of the shareholders (of both targets and acquirers) is significantly influenced by the reputation of the investment banks which have acted as advisors. This indicates that, subsequent to the shock of the Lehman Brothers collapse, the certifying effect of the investment banks takes on an important role in the shareholders' choice.

Keywords: Investment banking, financial advisory, M\&A transactions, Certification effect, Superior deal hypothesis 


\section{Introduction}

Merger and acquisition operations (M\&A) are one of the most important activities in the field of corporate finance and, in a parallel manner, within the sphere of the system of offer on the part of those who carry out investment banking activities. The importance of this phenomenon can be understood from the fact that in 2007, at the time of the most recent wave of M\&A activities, about 4.2 trillion dollars were invested in such activities at global level. In the meanwhile, the investment banks, acting as advisors for the counterparties in such operations, generated revenues in the form of fees for a value of approximately 39.7 billion dollars (Note 1), a fairly large slice of which was earned by only ten banks, which participated as advisors in most of the operations (Note 2). It is difficult to find empiric support in literature for the relationship between the reputation of the investment banks, appointed as advisors, and the quality of the services offered by these latter, and the results obtained are often discordant or not significant. Possible reasons for such discordances can be sought in the use of different methodologies according to the preferences of the authors of the empiric studies. Motivated by the new economic-financial context that has developed after the Lehman Brothers bankruptcy, which has presumably altered the competitive balances in the investment banking sphere, this paper illustrates the study of the relationship between the reputation of the investment banks and the quality of the services offered by these latter in the role of advisors in M\&A operations. According to previous literature (Capizzi, 2007a), the quality of the services offered would be expressed by the bank's capacity to increase the potential for creating value for the shareholders in a context of corporate mergers and acquisitions, i.e. the operations in which the control of a company is transferred by means of the conveyance of ownership. A distinctive feature of the research carried out, compared to previous literature, is represented by the focus on a sample of acquisitions and mergers which have taken place only between listed companies. This choice was made for several reasons. The first is that the reputation of the investment banks is not equally important in all transactions and its effects are more pronounced in situations which create a greater exposure to the reputation risk (Golubov, Petmezas and Travlos, 2012). As Rhee and Valdez (2009) suggest, greater visibility leads to higher potential damage to reputation. The second reason depends on the fact that in operations between listed companies it is more difficult for the counterparties to capture and release value in their own favour by means of the greater contractual power held by the listed companies compared to the non-listed companies. Therefore the acquisitions in which the target is also listed require greater skill and ability (Fuller, Netter, and Stegemoller, 2002) on the part of the advisors which assist the negotiation, in order to obtain maximum value from the transaction. For these reasons, the reputation of the investment banks can have a determining role in M\&A operations between listed companies (Golubov et al., 2012).

Having said this, focusing on a sample which includes only transactions between listed companies, the purpose of the empiric analysis is to verify if, on the occasion of a particular special financing event, there is any significant relationship between the creation of value for the shareholders and the reputation of the investment bank which assists the operation. This study, as already mentioned, has been carried out from the viewpoints of both the acquirer (or bidder) and the target (or seller). 


\section{M\&A Operations in Economic Literature}

The relationship between reputation, quality and price (Note 3) is dealt with in the models of Klein and Leffler (1981), Shapiro (1983) and Allen (1984). These models are applied to situations in which a subject repeatedly sells its own products on the market. When the quality of the product could be ascertained only after the purchase, a premium price was taken as a symbol of the high quality of the product. This premium price exists to compensate the seller for the resources used to create a better reputation for himself. The models, linked to a generic market, have then been applied by literature also to the provision of investment banking services. In fact, investment banks need to sell their own servicesi repeatedly and the quality of such services cannot be seen in advance. Since the investment banks are remunerated for the services which they offer continuously on the financial market and their permanence on such markets depends on the quality of the services supplied and the correct behaviour adopted, there is no doubt that in such a scenario the capital represented by a financial broker's reputation takes on a particularly important role. For example, Chemmanur and Fulghieri (1994) applied the model to equity underwriting services. In their model, investment banks with a high reputation gave better services and asked for higher fees. Literature has examined this theoretic model, and the considerable empiric evidence, above all relative to IPOs and SEOs, has confirmed the fundamental role of the bank's reputation in guaranteeing higher quality services and a more credible certification role of the value of the securities issued.

To conclude, it can be noted that the literature on the corporate control market also takes into consideration other viewpoints and other classifications of the financial brokers. For example, Allen, Jagtiani, Peristiani and Saunders (2004) have examined the role of trading banks as financial consultants. The authors have shown that the returns on the buy-side are not linked to whether they use their own trading bank as advisor in an M\&A operation. Recently, Song and Wei (2010) have concentrated instead on the role of the "boutiques (Note 4)" and on the comparison of these latter with the performances of the traditional investment banks, which offer complete investment banking services. The preceding studies found that the boutiques are more used in small transactions and that the acquirers who take avail of boutiques in acquisitions of listed companies manage to pay lower fees. However, this does not mean greater abnormal returns and, in spite of the popularity of such advisors in recent years, there is no concrete evidence as yet that a company can obtain benefits firom the choice of boutiques rather than investment banks which cover a wider range of services. Lastly, another conclusion of the study is the fact that, in general, the fees requested by the boutiques are about the same as those charged by the traditional investment banks (Song and Wei, 2010).

\section{The Role of Advisory Services in M\&A Operations}

There are many reasons why a company's management decides to undertake M\&A operations. One of the main reasons is expansion (Gaughan, 2011). Company acquisitions therefore represent a way of pursuing growth, as an alternative to the strategic option of growth by internal lines. In this sphere the synergies, as main factors of the creation of value, represent a decisive reason at the basis of M\&A operations. The other determining factors for a company acquisition are the benefits that the buyers and sellers expect as the result of an M\&A 
operation. Ravenscraft and Scherer (1987) describe how sellers sell when buyers make sufficiently attractive offers. The M\&A activity is therefore often influenced by a number of factors. These include regulations, market dimensions, technological innovation, fluctuations in the financial markets and financial innovations. Furthermore, stimuli, opportunities and risks which develop in the market can then become strategic options, sources of synergies, which determine the convenience of an operation (Capizzi, 2007).

For the companies directly controlled, M\&A can have a strategic content of particular relevance(Capizzi, 2007) (Note 5). Considering the importance of such events, one can imagine the wide range of areas of competence touched by special underwriting operations and how M\&A activity becomes an extraordinarily important field for advisory services, which can include a wide range of activities. As pointed out by Servaes and Zenner (1996), companies intending to acquire the control of another company usually take avail of an advisor when the transaction is perceived as complex and when the managers do not have the benefit of past experience gained from other acquisitions.

The hypothesis underlying the decision to put oneself in the hands of an investment bank is that these institutes should be able to help their customers in identifying the best targets. However, as resulting from the review of the literature, some existing studies follow a different direction and do not point out any positive relationship between the bank's reputation and the buyer's performance (the most beaten track). Other results seem to support the hypothesis of a passive execution of the operations, in which the banks do not supply real consultancy services with added value, but merely follow the instructions issued by the customer (Bao and Edmans, 2011). However, returning to the reasons for the demand for advisory services and leaving aside the arguments concerning the effective added value that may or may not be contributed by the activity of the investment banks, which questions will be answered further below, the general reasons for requesting an advisor can be classified under four main types (Capizzi, 2007a). A first type regards the financial broker's capacity to reduce the costs of a transaction on the corporate ownership and control reallocation market (Buongiorno and Conca, 2007). A second type is connected with the existence of informative asymmetries, which is a factor which increases the need for advice, given the superior ability and efficiency of financial brokers in obtaining, producing and managing information on relevant aspects relative to which the interests of the counterparties engaged in a given transaction normally diverge. A third type of reason which justifies the need to take avail of an advisor is the "certification effect" which the latter can give. A last type of reason derives, instead, from the context of bank-broker relationships covering different periods. As shown by certain studies, the fees for the advisory service performed to assist M\&A operations often include a sort of "relationship fee" recognised to the investment bank which has already acted as an advisor for a given company on the occasion of previous M\&A operations (Capizzi, 2007a) (Note 6). Therefore, to sum up, why are investment banks often necessary to undertake an important special financing operation? The banks in question deal with the technical aspects of the transactions: they collect and process the available information on the companies involved in the transaction, they suggest the best options in terms of how to structure the operation, they assist their customer companies in negotiating the terms of the deal, they give an opinion (a fairness opinion, if requested) on the suitability of the price 
negotiated. It is a question of informative asymmetries: if a company were capable of interacting independently with the financial markets so that they could certify the quality of their own products (shares, bonds, etc.), the investment banks would have no reason to exist. Taking into account all the above considerations, one can sum up by saying that the fundamental role of the investment banks in the sphere of special financing operations is that of obtaining and processing the available information in order to certify the quality of the operation on the basis of their own experience and reputation. Lastly, the higher the advisor's reputation, the greater the so-called certification effect.

\section{The "League Tables" of the Investment Banks}

To get an idea of the actors present in the investment banking industry, one must look at the "league tables". The "league tables" are classifications of the investment banks in a given business: classifications are available for M\&A, IPO, bond issue operations, etc. The investment banks place great importance on the league tables, since they are an important marketing tool. To get evidence of a bank's leadership in a certain sector/business, the only objective tool that can be used to verify whether the statements are correct or not are the league tables. One of the features of these tables is that they tend to be stable over the medium-long term, especially as regards the first positions; in other words, the leading banks, i.e. those which have the highest reputations and market shares in the sector, are constantly in the top positions of the league tables. However, some changes have taken place with the recent financial crisis, which made some large banks bankrupt (for example, Lehman Brothers) and which forced others to carry out deep reorganisation.

With regard to the technical aspects, it must be noted that there are normally three possible criteria according to which a league table is constructed (Note 7): the value of the operations (or deal values), the commissions (or fees) and the number of operations. The most used criterion is by far the first (Note 8).

\section{The Empiric Analysis}

\subsection{The Research Question}

In literature, the main studies on the role of investment banks in M\&A operations have examined the effect of the reputation of the banks on the return for the shareholders of their client companies. In particular, the research in question hinges mainly on the hypothesis referred to, historically, in literature by the expression: "the superior deal hypothesis". This hypothesis indicates that the banks with the higher reputation have the capacity of both identifying the best counterparties and of structuring the best deals, increasing the potential creation of value in a special financing operation (Ismail, 2010). Consequently, according to this hypothesis, there is a positive link between the reputation of the investment banks and the creation of value for the shareholders.

The idea is therefore based on the fact that the top investment banks are able to give services of a superior quality. Considering that the quality of the more important activities included within the investment banking services depends critically on a bank's experience (Ma, 2006), the reason for the importance of the role of the league tables in measuring the value of the banks' reputation can be understood. This greater respect is recognised to the main 
investment banks because of the know-how they have gained due to the fact that they have been involved in a greater number of transactions dealing with many different sectors, countries and customers. In addition, thanks to their greater experience, the bankers of the top investment banks ought to have greater negotiating capacity and consequently better results for their customers. Secondly, returning to the concept of reputation and of the certification role played by the financial broker, in literature the certification hypothesis, defined in respect of investment banking activities, suggests that the more prestigious brokers, whose leading positions in the league tables are confirmed, ought to reduce the uncertainty of the markets on the effective quality of the operation. Taking into consideration the new economic-financial context resulting from the financial crisis, and considering the division of the analysis into two symmetrical periods, it is hypothesised that in the pre-Lehman period, featuring a strongly growing market and intense M\&A activity, the reputation of the banks did not necessarily indicate better returns for the shareholders, since the market was highly irrational, and the certification effect lost importance. However, the banks are expected to have a more important role in certifying the value of a certain transaction in a period (post Lehman, when the financial crisis has spread wildly) when uncertainty has become an important feature of the market.

\subsection{The Dataset Used}

A sample of M\&A transactions has been collected over a period of 8 years, from 15 September 2004 to 15 September 2012. For the purposes of the analysis, the time frame has been divided into two symmetrical parts: the 4 years before and the 4 years after 15 September 2008 (Note 9). The choice of these two periods was made to make the periods observed more similar and more comparable. The data were collected thanks to the financial data provider (ThomsonOne Investment Banking (Thomson Reuters)) and regard announcements of operations, then completed, between companies located in the following West European countries: Austria, Belgium, Denmark, Finland, France, Germany, Greece, Ireland, Iceland, Italy, Luxembourg, Norway, Holland, Portugal, United Kingdom, Spain, Sweden, Switzerland (the same 18 countries considered by the STOXX Europe 600 Index, which is the market index which has been taken as a benchmark, as will be indicated further below). To belong to such countries is relevant for both the target and the acquirer. The initial sample was expanded by applying additional selection criteria, in order to obtain a dataset with features appropriate for the analysis carried out. In particular, the following transactions were excluded: those with a deal value below $€ 1 \mathrm{~m}$; those in which target and acquirer were not both listed; those which regarded shares representing less than $5 \%$ of the target's total equity. In addition, wishing to pay great attention to transactions implying the transfer of the control, the only operations considered were those in which the acquirer held less than $50 \%$ of the shares initially and more than $50 \%$ of the shares afterwards. Then, in view of the fact that the purpose of the analysis was to study the relationship between the results of the operation and the advisor's reputation, all the transactions in which the provider did not give any indication of an advisor were also excluded. This information may have been concealed for the sake of confidentiality, for which reason the terms of the operation and/or the consultants involved were not disclosed, or it may have been because the companies chose 


\section{MlMacrothink}

not to take avail of external consultants. Explicit reference is made in literature to such operations, defining them as "in-house deals" (Servaes and Zenner, 1996). Lastly, to avoid distortions in the results due to the particular economic situation in the more recent of the two periods observed, all operations involving targets or acquirers belonging to the financial services sector were also eliminated from the sample.

\subsubsection{The Classification of the Investment Banks}

Literature offers various indications for measuring the reputation of the investment banks (Note 10). In spite of the many different methods, considering the many studies which hinge on these matters, it is reasonable to suppose that literature, relative to the corporate control market, considers as a good proxy for the reputation and quality of the investment banks, the market share held by the same, understood as the accumulated counter value of the deals followed as a percentage of the total value of the deals in a given geographic area and in a specific time frame (see the preceding section on league tables). In particular, to classify the investment banks for the purposes of this analysis, two methods have been followed, one of which was used as the control method. The first is based on the rankings which can be obtained directly from the financial data provider, Thomson Reuters, while the second method is more linked to the particular physiognomy of the transactions sample used for the empirical analysis. Since the research focused on West Europe, the annual rankings were downloaded from the Thomson Reuters' M\&A League Tables section, based on the accumulated deal values of the operations announced in each year of the time frame of the sample. Placing the positions in order of size, an absolute classification of the investment banks can be drawn up (Note 11). Table 1 shows the first twenty banks (Note 12) (Table 1).

Table 1. Investment banks: ranking (league table)

\begin{tabular}{|l|c|c|c|c|c|c|c|c|c|c|c|}
\hline ADVISOR & 2012 & 2011 & 2010 & 2009 & 2008 & 2007 & 2006 & 2005 & 2004 & Average Position & RANK \# \\
\hline Goldman Sachs & 1 & 1 & 1 & 7 & 5 & 1 & 2 & 1 & 2 & 2,3 & 1 \\
\hline Morgan Stanley & 2 & 2 & 2 & 3 & 3 & 4 & 1 & 4 & 5 & 2,9 & 2 \\
\hline Deutsche Bank & 3 & 3 & 3 & 2 & 8 & 6 & 10 & 6 & 7 & 5,3 & 3 \\
\hline JP Morgan & 6 & 8 & 7 & 6 & 1 & 7 & 6 & 2 & 6 & 5,4 & 4 \\
\hline Citi & 9 & 10 & 10 & 4 & 4 & 2 & 4 & 7 & 3 & 5,9 & 5 \\
\hline Rothschild & 10 & 4 & 5 & 8 & 11 & 8 & 5 & 5 & 1 & 6,3 & 6 \\
\hline UBS & 14 & 6 & 12 & 1 & 2 & 5 & 8 & 9 & 13 & 7,8 & 7 \\
\hline Bank of America Merrill Lynch & 15 & 13 & 14 & 11 & 6 & 3 & 3 & 3 & 4 & 8,0 & 8 \\
\hline Credit Suisse & 7 & 11 & 4 & 5 & 7 & 9 & 11 & 12 & 12 & 8,7 & 9 \\
\hline BNP Paribas & 5 & 16 & 8 & 12 & 10 & 11 & 7 & 8 & 9 & 9,6 & 10 \\
\hline Lazard & 12 & 9 & 6 & 9 & 9 & 15 & 9 & 15 & 10 & 10,4 & 11 \\
\hline Nomura & 8 & 15 & 15 & 23 & 15 & 10 & 12 & 10 & 16 & 13,8 & 12 \\
\hline HSBC & 19 & 7 & 11 & 18 & 20 & 21 & 13 & 14 & 19 & 15,8 & 13 \\
\hline Societe Generale & 17 & 5 & 9 & 15 & 12 & 26 & 15 & 22 & 29 & 16,7 & 14 \\
\hline Credit Agricole & 13 & 12 & 17 & 21 & 19 & 24 & 14 & 13 & 30 & 18,1 & 15 \\
\hline Mediobanca & 21 & 21 & 26 & 16 & 16 & 14 & 20 & 18 & 14 & 18,4 & 16 \\
\hline RBS & 37 & 31 & 20 & 13 & 23 & 12 & 16 & 16 & 8 & 19,6 & 17 \\
\hline UniCredit & 42 & 19 & 19 & 24 & 25 & 23 & 37 & 21 & 15 & 25,0 & 18 \\
\hline Santander & 39 & 34 & 37 & 25 & 18 & 13 & 22 & 35 & 24 & 27,4 & 19 \\
\hline Leonardo \& Co & 35 & 22 & 33 & 26 & 26 & 25 & 17 & 19 & 46 & 27,7 & 20 \\
\hline
\end{tabular}

Source: Thomson Reuters (2004-2012). 


\section{Nl Macrothink}

The first ten banks are identified as top investment banks. In the following table (Table 2), each investment bank present in the sample of transactions has been accredited the deal value of every transaction in which it has participated. If one of the companies (whether target or acquirer) involved in the operation has taken avail of several advisors simultaneously, the deal value of the transaction is attributed to all the advisors involved. The bank which has obtained the highest cumulative deal value has then been assigned first place, that with the second highest deal value has been placed second, and so on down to the bank which has given its assistance for the lowest cumulative value. This procedure has produced the following result in Table 2 .

Table 2. Investment banks: deal value

\begin{tabular}{|l|c|c|}
\hline ADVISOR & DEAL VALUE $(€ \mathrm{~m})$ & RANK \# \\
\hline Morgan Stanley & 149.172 & 1 \\
\hline Goldman Sachs & 129.131 & 2 \\
\hline JP Morgan & 128.928 & 3 \\
\hline Bank of America Merrill Lynch & 107.782 & 4 \\
\hline Citi & 104.063 & 5 \\
\hline UBS & 97.319 & 6 \\
\hline Credit Suisse & 86.064 & 7 \\
\hline Deutsche Bank & 79.422 & 8 \\
\hline BNP Paribas & 61.722 & 9 \\
\hline Lazard & 56.506 & 10 \\
\hline HSBC & 39.757 & 11 \\
\hline ABN-AMRO & 39.647 & 12 \\
\hline Rothschild & 36.958 & 13 \\
\hline Societe Generale & 36.847 & 14 \\
\hline Santander & 25.772 & 15 \\
\hline Greenhill \& Co & 20.707 & 16 \\
\hline Dresdner Kleinwort Wasserstein & 18.897 & 17 \\
\hline Lehman Brothers International & 14.410 & 18 \\
\hline Perella Weinberg Partners & 13.722 & 20 \\
\hline Credit Agricole & 12.194 & \\
\hline
\end{tabular}

Source: Thomson Reuters.

To avoid distortions due to the particular choices made during the selection phase and when constructing the sample of the transactions, and to obtain a more absolute and objective assessment of the reputation of the investment banks, the first method was chosen, which derives from a general consideration of the entire M\&A market in West Europe.

\subsubsection{Descriptive analysis of the sample}

Following the selection criteria outlined in section 3.2.1, a sample of sufficiently similar M\&A operations was obtained. After a few small modifications which were made due to particular needs within the sphere of the empiric analysis (elimination of the observations corresponding to the maximum and minimum CARs (Kale et al., 2003)), the final sample was composed of 229 observations. In particular, these observations are divided into 68 transactions announced after the date of the Lehman Brothers bankruptcy and 161 
transactions announced before the bankruptcy. The difference in terms of the number of transactions between one period and another gives an idea of the decrease in the activity which was typical immediately after the bankruptcy and in the period of the financial crisis in general.

Dividing targets and acquirers according to the macro sector (or macro industry (Note 13)) to which they belong, it can be observed that the companies of our sample are distributed among the various sectors and, consequently, how the M\&A activity in each sector differs between the two periods considered (Table 3). It can be noted, in particular, that in the four years before the Lehman Brothers Bankruptcy, transactions involving targets of the high technology (HT) sector were predominant, while in the successive four years this type of transaction decreased sharply (87.5\% fewer), going from 40 (pre Lehman) to 5 (post Lehman) acquisitions of high-tech companies. Comparing the two periods, a particular fall can also be seen in transactions aimed at acquiring consumer goods (CPS and STAPLES). To this regard, the fall of the activity is greater in the case of companies which produce the so-called 'consumer staples', i.e. consumer goods which are not cyclical, which are primary, like food and beverages. In this case, the analysis of our sample shows a change from 13 to 2 acquisitions of companies belonging to this sector (a fall of about 85\%). An explanation for this tendency can be found in the general reduction of consumptions at the macro level which may have slowed down the growth of the sectors connected, in particular, to the available income and to individuals' tendency to consume. On the contrary, a certain equilibrium can be seen in the M\&A operations for the acquisition of companies in the Energy and Power sector or the Health Care sector. (Table 3 ).

Table 1. Macro industry

\begin{tabular}{|l|c|c|c|c|c|c|}
\hline \multirow{2}{*}{ Macro Industry } & \multicolumn{2}{|c|}{ Pre Lehman } & \multicolumn{2}{c|}{ Post Lehman } & \multicolumn{2}{c|}{ Intero periodo } \\
\cline { 2 - 7 } & Targets & Acquirers & Targets & Acquirers & Targets & Acquirers \\
\hline ENERGY & 11 & 12 & 9 & 9 & 20 & 21 \\
\hline IND & 18 & 21 & 13 & 14 & 31 & 35 \\
\hline HT & 40 & 28 & 5 & 6 & 45 & 34 \\
\hline TELECOM & 7 & 18 & 4 & 3 & 11 & 21 \\
\hline RETAIL & 9 & 11 & 4 & 4 & 13 & 15 \\
\hline HEALTH & 11 & 9 & 9 & 7 & 20 & 16 \\
\hline MEDIA & 10 & 12 & 3 & 6 & 13 & 18 \\
\hline REALEST & 9 & 8 & 5 & 5 & 14 & 13 \\
\hline MATERLS & 16 & 16 & 9 & 9 & 25 & 25 \\
\hline CPS & 17 & 16 & 5 & 2 & 22 & 18 \\
\hline STAPLES & 13 & 10 & 2 & 3 & 15 & 13 \\
\hline
\end{tabular}

Analysing "Table 4", it can be seen that, on average, there are more companies which do not take avail of a first tier advisor than those which do. However, since we have classified only ten investment banks as first tier advisors, it is in any case surprising to note that, during the entire time frame, these are taken into consideration by targets in $41 \%$ of cases and by acquirers in $46 \%$ of cases. Observing Table 4 in detail, it is also curious to notice that while the request for first tier banks on the part of buyer companies has remained stable in both the 
pre-Lehman and the post-Lehman periods, the request on the part of target companies for advisors with a high reputation decreased considerably after the bankruptcy (when the financial crisis was spreading uncontrollably). In particular, compared to an average of $41 \%$ over the entire time frame of eight years, only $29 \%$ of the 68 target companies of the sample in the post Lehman period sought support from a top advisor. One explanation for this phenomenon could be the need, due to the particular economic situation, to apply to consultants which required relatively much lower fees (this is the hypothesis underlying the theory of Saunders and Srinivan (2001), according to whom the top advisors general ask for much higher fees than the second tier advisors). However, this motive does not explain why the same phenomenon does not also appear in the case of the bidders.

Table 2.

\begin{tabular}{|c|c|c|c|}
\hline & Pre Lehman & Post Lehman & Entire period \\
\hline Targets with top-tier advisor & 75 & 20 & 95 \\
\hline$\%$ & $47 \%$ & $29 \%$ & $41 \%$ \\
\hline Targets without top-tier advisor & 86 & 48 & 134 \\
\hline$\%$ & $53 \%$ & $71 \%$ & $59 \%$ \\
\hline Acquirers with top-tier advisor & 76 & 29 & 105 \\
\hline$\%$ & $47 \%$ & $43 \%$ & $46 \%$ \\
\hline Acquirers without top-tier advisor & 85 & 39 & 124 \\
\hline$\%$ & $53 \%$ & $57 \%$ & $54 \%$ \\
\hline
\end{tabular}

To conclude, the features of the sample, in terms of the size of the operations, using the deal values of the same as proxy, can now be observed. It can be seen, from "Table 5", that in the four years after the Lehman crash, the dimensions of the transactions of our sample were considerably smaller than those of the "pre-crisis" period. The average deal value fell from $€$ $1,606 \mathrm{~m}$ before the crash to $€ 466 \mathrm{~m}$ after the crash. This enormous difference can be explained by the fact that after the crash (in the period of the global financial crisis) the maximum sizes of transactions throughout the whole world decreased considerably. It can be seen from the column "Maximum" of "Table 5" that the simple sample considered for the purpose of the research shows this trend inversion. The largest transaction before the Lehman Brothers bankruptcy (and before panic spread through the financial markets), had a deal value of $€ 26,225 \mathrm{~m}$ against a deal value of $€ 3,416 \mathrm{~m}$ of the largest transaction of the sample taking place after 15 September 2008.

Table 3.

\begin{tabular}{|l|c|c|c|c|c|c|}
\hline \multirow{2}{*}{ Period } & \multirow{2}{*}{$\mathrm{N}$} & \multicolumn{5}{|c|}{ Descriptive statistics $(€ \mathrm{~m})$} \\
\cline { 3 - 7 } & & Mean & Median & Minimum & Maximum & Range \\
\hline Pre Lehman & 161 & 1,606 & 228 & 2 & 26,225 & 26,223 \\
\hline Post Lehman & 68 & 466 & 134 & 2 & 3,416 & 3,414 \\
\hline Entire period & 229 & 1,267 & 189 & 2 & 26,225 & 26,223 \\
\hline
\end{tabular}


Table 4. Sell-side deal value descriptives statistics (€m)

\begin{tabular}{|c|c|c|c|}
\hline & Sell-side deal & descriptives & \\
\hline \multirow{10}{*}{ Pre Lehman } & \multirow{5}{*}{ No top-tier advisor } & Mean & 217 \\
\hline & & Median & 88 \\
\hline & & Minimum & 2 \\
\hline & & Maximum & 2.711 \\
\hline & & Range & 2.709 \\
\hline & \multirow{5}{*}{ With top-tier advisor } & Mean & 3.198 \\
\hline & & Median & 837 \\
\hline & & Minimum & 18 \\
\hline & & Maximum & 26.225 \\
\hline & & Range & 26.207 \\
\hline \multirow{10}{*}{ Post Lehman } & \multirow{5}{*}{ No top-tier advisor } & Mean & 204 \\
\hline & & Median & 64 \\
\hline & & Minimum & 2 \\
\hline & & Maximum & 2.822 \\
\hline & & Range & 2.820 \\
\hline & \multirow{5}{*}{ With top-tier advisor } & Mean & 1.095 \\
\hline & & Median & 644 \\
\hline & & Minimum & 25 \\
\hline & & Maximum & 3.416 \\
\hline & & Range & 3.392 \\
\hline \multirow{10}{*}{ Entire period } & \multirow{5}{*}{ Notop-tier advisor } & Mean & 212 \\
\hline & & Median & 76 \\
\hline & & Minimum & 2 \\
\hline & & Maximum & 2.822 \\
\hline & & Range & 2.820 \\
\hline & \multirow{5}{*}{ With top-tier advisor } & Mean & 2.756 \\
\hline & & Median & 809 \\
\hline & & Minimum & 18 \\
\hline & & Maximum & 26.225 \\
\hline & & Range & 26.207 \\
\hline
\end{tabular}

Furthermore, considering the dimensions of the deals and the presence, or absence, of top tier advisors, it can be seen that the first tier investment banks are more engaged in transactions of relatively greater dimensions on both the sell-side and the buy-side. Consider the following tables, Table 6 and Table 7, for target and bidder companies respectively. The tables show that the phenomenon according to which the top-tier banks are used in transactions of greater dimensions holds firm in all the time frames considered. For the target companies, in general (without considering the division between the two specular periods), a top advisor has given consultancy services in transactions with an average deal value of $€ 2,756 \mathrm{~m}$ while it was not engaged (or did not agree to offer its services) in relatively smaller transactions, for an average deal value of $€ 212 \mathrm{~m}$. The table also confirms the conclusions on the diverse dimension of the transactions in the two symmetrical periods. The average value of the operations, assisted by a top investment bank, decrease, in fact, from $€ 3,198 \mathrm{~m}$ in the 
pre-crash period to $€ 1,095 \mathrm{~m}$ in the post-crash period. A similar phenomenon can also be seen in respect of the bidders. In general, they also take avail of top investment banks for transactions of relatively greater dimensions. In detail, referring to the entire time frame covered by the sample, it can be seen that the average value of the deals assisted by at least one top-tier investment bank is $€ 2,366 \mathrm{~m}$ against an average deal value of $€ 337 \mathrm{~m}$ for transactions carried out without the services of a top investment bank.

Table 5. Buy side deal value descriptive statistics (€m)

\begin{tabular}{|c|c|c|c|}
\hline \multicolumn{4}{|c|}{ Buy side deal value descriptive statistics $(€ m)$} \\
\hline \multirow{10}{*}{ Pre-Lehman } & & Mean & 410 \\
\hline & & Median & 104 \\
\hline & No top-tier advisor & Minimum & 2 \\
\hline & & Maximum & 16,910 \\
\hline & & Range & 16,908 \\
\hline & & Mean & 2,944 \\
\hline & & Median & 802 \\
\hline & With top-tier advisor & Minimum & 14 \\
\hline & & Maximum & 26,225 \\
\hline & & Range & 26,211 \\
\hline \multirow{10}{*}{ Post-Lehman } & & Mean & 178 \\
\hline & & Median & 62 \\
\hline & No top-tier advisor & Minimum & 2 \\
\hline & & Maximum & 2,012 \\
\hline & & Range & 2,010 \\
\hline & & Mean & 853 \\
\hline & & Median & 357 \\
\hline & With top-tier advisor & Minimum & 6 \\
\hline & & Maximum & 3,416 \\
\hline & & Range & 3,411 \\
\hline \multirow{10}{*}{ Entire period } & & Mean & 337 \\
\hline & & Median & 88 \\
\hline & No top-tier advisor & Minimum & 2 \\
\hline & & Maximum & 16,910 \\
\hline & & Range & 16,908 \\
\hline & & Mean & 2,366 \\
\hline & & Median & 671 \\
\hline & With top-tier advisor & Minimum & 6 \\
\hline & & Maximum & 26,225 \\
\hline & & Range & 26,220 \\
\hline
\end{tabular}

In addition, it can be seen that the re-sizing of the deal values between the pre Lehman crash period and the post Lehman crash period is also confirmed by the analysis of the buyer companies. However, it is curious to note that this difference, in the average dimensions of the operations, is not so evident for those carried out without the services of a top advisor. This confirms the hypothesis according to which companies are more inclined to request the assistance of a top investment bank in complex M\&A operations with relatively higher dimensions (Servaes and Zenner, 1996). 


\subsection{The Event Study Methodology}

This section focuses on the description of the event study approach. This is an analysis method which, by examining the changes in share prices, allows for estimating the impact generated by a specific corporate event. In this context, the term "event" refers to facts or information which, if made public, can significantly alter the value of a listed company. The use of this method is based on the fact that the entity of an abnormal share performance, measured around the time of a certain company event, can allow for assessing the impact that this certain event will have on the wealth of the shareholders of a certain company (Kothari and Warner, 2007). According to the hypothesis of efficient markets, the prices reflect all the information publicly available on a particular asset (Fama, 1970). As far as concerning this analysis, all the observations considered regarding the sample correspond to events (M\&A announcements) taking place at different moments: the first public announcement of a certain M\&A operation is the most suitable moment to measure the impact (Halpern,1983). It is worth remembering that abnormal returns exist and that they can be measured even before the effective announcement, usually because of leaks of confidential information and/or because the market itself gives advance notice of the event (Keown and Pinkerton, 1981). However, since the market cannot entirely predict an event, an abnormal share trend can be observed and can therefore be ascribed to the event itself.

The standard method followed is divided into several steps: a) definition of the event of interest and identification of the period of time (the so-called event window) over which to examine the impact that the event has had on the price of the shares; estimate of the expected return; b) calculation of the abnormal return; c) verification of the zero hypothesis and d) interpretation of the results.

Before describing the method which will lead to the final result, it is necessary to clarify two basic concepts:

- estimation window: the period of time over which to estimate the normal market return. This period is prior to the event, to avoid the announcement influencing the estimate of the parameters;

- event window: the period of time, including at least the day of the event, over which to examine the impact that the said event has had on the share price.

To check the existence of abnormal returns, a benchmark (Note 14) for normal returns (not influenced by a particular event) is necessary and, without doubt, it must be defined correctly. In fact, many models can be found in literature, associated with the event study methodology, for estimating expected returns. And the precision of the abnormal returns can differ according to the various alternative methods. However, an extensive study of the literature on the different methods has allowed for underlining the properties and the advantages and disadvantages of each method. Literature concentrates in particular on two models: the constant mean return model and the market model. The first presumes that the average return on the security is constant over time; the second associates the return on the financial instrument with the return on the relative market portfolio and it is based on the assumption of the normality of the returns. Several authors (Panayides and Gong, 2002, Davidson, Dutia and Cheng, 1989) have demonstrated that the market model gives the more accurate 
measurement of the abnormal returns. Considering that the event of interest to our analysis is the announcement of a corporate merger or takeover, which takes place on a specific, identifiable day, it goes without saying that the study of the events is based on daily data (Brown and Warner, 1985) (Note 15). With regard to the estimation (Note 16) of the parameters $\alpha$ (alpha) and $\beta$ (beta) of the equity of the company in question, an estimation window prior to the event (the announcement of the operation) was used, in order to avoid excessive contamination deriving from the effects of possible rumours on the operation. Beta, which expressed the behaviour of a security in respect of the market of reference, in statistical terms is the angular coefficient of the straight line of the regression of the return on the equity instrument, compared to the return of the market index used as the benchmark. A beta of 1 indicates that the security moves perfectly in line with the market of reference, whereas a beta of more than 1 indicates an aggressive security which amplifies the market movements, and a beta of less than 1 indicates a more conservative security, particularly insensitive to market movements, which a less marked volatility than the invoice take as comparison (Allen, Brealey, Myers and Sandri, 2007). The beta coefficient $(\alpha)$ measures the aptitude of a security to vary according to the market (systematic risk) while the alpha $(\beta)$, which intercepts the straight line of the regression, expresses the aptitude of a security to vary independently of the market (specific risk). In order to calculate the parameters, it was decided to use an estimation window of 150 days, from 170 to 20 days before the event date (date of the announcement) except in some special cases in which the period was reduced by a few days because of the lack of financial data. This occurred because the company involved in a certain M\&A operation was still not listed when the financial data were taken. In addition, careful attention was paid to check that, during the estimation window, the companies in question had not undertaken or had not been subjected to other extraordinary operations. In fact, those which presented this flaw were eliminated from the sample.

The first step in the execution of the analysis was to make a regression between the returns on a specific security $i$ and the returns of the market index $m$ (the STOXX Europe 600 Index) . The angular coefficient, $\hat{\beta}_{i}$, is the value of the beta while $\hat{\alpha}_{i}$ is the interception point, on the ordinates axis, of the straight line of the regression. Assuming a constant beta for a given security $i$, we calculate the expected return on the security $i$, for every day of the event window, according to the following equation:

$$
\bar{E}_{i t}=\hat{\alpha}_{i}+\hat{\beta}_{i} R_{m t}
$$

where $\bar{E}_{i t}$ is the expected return (Note 17 ) at time t, $R_{m t}$ is the daily return of the market index $m$ at time $t, \hat{\alpha}_{i}$ and $\hat{\beta}_{i}$ are the regression parameters.

The effective yield of a security $i$ is defined as:

$$
R_{i t}=\hat{\alpha}_{i}+\hat{\beta}_{i} R_{m t}+\varepsilon_{i t} \text { with } E\left(\varepsilon_{i t}\right)=0, E\left(\varepsilon_{i t}\right)^{2}=\sigma_{\varepsilon}^{2}
$$

Therefore, the abnormal return is defined as the difference between the effective return on a security $i\left(R_{i t}\right)$, observed on the market at a particular time $t$ (and conditioned by the particular event), and its expected return $\bar{E}_{i t}$ at time $t$ (not influenced by the event). Therefore, the abnormal return on a security $i$ at time $t$ is given by the equation: 


$$
\text { ARit }=\text { Rit }-\bar{E} i t=\varepsilon_{i t}
$$

Where $R_{i t}$ is the actual return on the security $i$ at time $t$. The abnormal return can be considered as the direct entity of the unexpected difference in the shareholders' wealth associated with the event. The cumulative abnormal return on a security $i$ results from the sum of the daily abnormal returns observed over a given period (event window) $\left[t_{0}, t_{1}\right]$ :

$$
\operatorname{CAR}_{i}\left(t_{0}, t_{1}\right)=\sum_{t=t_{0}}^{t_{1}} A R_{i t}=\sum_{t=t_{0}}^{t_{1}} \varepsilon_{i t}
$$

The average abnormal return is the average of the abnormal returns calculated for each observation, for every day $t$ of the event window:

$$
A A R_{t}=\frac{1}{N} \sum_{i=1}^{N} A R_{i t}
$$

The average of the CARS, however, is defined as cumulative average abnormal returns:

$$
\operatorname{CAAR}_{i}\left(t_{0}, t_{1}\right)=\frac{1}{N} \sum_{i=1}^{N} C A R_{i, t_{0}, t_{1}}=\sum_{t=t_{0}}^{t_{1}} A A R_{t}
$$

In this work, the calculation of the CARs is based on an event window of five days (Ismail, 2010; Golubov et al., 2012). These five days include: the two days before the announcement, the day of the announcement (time zero) and the two days after the announcement $(-2,+2)$. The wish to include data prior to the announcement is linked to the possibility of rumours which can influence the returns on the shares (Note 18). The data after the announcement, instead, are justified by the possible presence of a time lag between the announcement and the reaction of the market.

To check that the resulting CARs are statistically not zero (i.e. significant from a statistical viewpoint), the statistical $t$-test and its $p$-value are used. With the t-test, it is possible to obtain a probabilistic measure regarding the coincidence of the average of the sample with that of the distribution "student $t$ ". What one intends to verify, i.e. the case of zero $\mathrm{H}_{0}$, is:

$$
H_{0}: C A A R_{t_{0}, t_{1}}=0
$$

$H_{1}: C A A R_{t_{0}, t_{1}} \neq 0$

By the identification of the p-value, it is then established whether to refuse the zero hypothesis or not. In the case in question, it was decided to refuse the zero hypothesis if the p-value was below $5 \%$, accepting the risk of committing a prima specie error (refusing the zero hypothesis when it is true) with a probability of $5 \%$. When the p-value is below that threshold, it can be said that the average of the CARs is not statically different from zero. 


\subsection{The Results}

We will now go on to analyse the results of the event study and of the statistical test (Note 19). First of all, in accordance with Kale et al. (2003), in order to limit the influence of particular outliers, the observations corresponding to the extreme values (maximum and minimum) in terms of CARs, were eliminated from the sample. In general, in previous literature, a positive effect was found for the target, while the market reaction for the acquirer was negative or insignificant. According to literature, averagely positive and significant CARs were observed for the targets, while the CARs observed for the bidder companies were in general not significantly different from zero. In the case in point, however, it is curious to notice what happens when we test the zero hypothesis considering different time frames (respectively pre and post Lehman). First of all, if one considers the entire time frame of our sample (therefore all the 229 observations), a strong positive and statistically significant return can be seen for the targets while the result for the buyer companies is not statistically significant (Table 8). We can see, in particular, that for the event window $(-2,+2)$ the targets obtain, on average, a cumulative return of $14.90 \%$ with a $p$-value equal to 0.000 . The average return for the acquirers, instead, does not differ relevantly from zero and the p-value (equal to 0.251 ) conforms the zero hypothesis according to which the CARs do not differ statistically from zero (Table 8).

Table 6.

\begin{tabular}{|c|c|c|c|c|c|c|}
\hline \multicolumn{7}{|c|}{ One-Sample Test } \\
\hline & \multicolumn{6}{|c|}{ Test Value $=0$} \\
\hline & \multirow{2}{*}{$\mathrm{t}$} & \multirow{2}{*}{$\mathrm{df}$} & \multirow{2}{*}{ Sig. (2-tailed) } & \multirow{2}{*}{ Mean Difference } & \multicolumn{2}{|c|}{$95 \%$ Confidence Interval of the Difference } \\
\hline & & & & & Lower & Upper \\
\hline CAR TARGET $(-2,+2)$ & 12,496 & 228 & , 000 & 14897514 & 12548476 & 17246552 \\
\hline CAR ACQUIROR $(-2,+2)$ & $-1,151$ & 228 & 405 &,- 00296506 &,- 00996326 &, 00403313 \\
\hline
\end{tabular}

IOD

However, if we consider the sample of observations divided into the two time frames, we obtain different results. It must be remembered that the 229 observations were divided into 161 pre-crash observations and 68 post-crash observations. With regard to the targets, however, the results are not very different. The CARs are on average strongly positive and significant for both time frames. In spite of this, it can be noted, in detail, that the average returns are slightly higher in the post-crash period (Table 10) and slight lower in the pre-crash period (Table 9). This could be interpreted by supposing greater prudence was exercised in the period of the crisis when undertaking M\&A operations, which greater prudence would have led to more in-depth assessments and a greater selection in favour of only operations which guaranteed greater synergies. However, such conclusions cannot be drawn in respect of the buyer companies. It can be seen that the p-values of these latter prior to the crash are extremely high, and then fall considerably after the crash, ending up below the $5 \%$ level ( $p$-value equal to 0.037 ). In this case, the resulting average CAR is negative, equal to $1.42 \%$, and statistically significant (Table 10). 
Table 7.

\begin{tabular}{|c|c|c|c|c|c|c|}
\hline \multicolumn{7}{|c|}{ One-Sample Test $^{a}$} \\
\hline & \multicolumn{6}{|c|}{ Test Value $=0$} \\
\hline & \multirow{2}{*}{$\mathrm{t}$} & \multirow{2}{*}{ df } & \multirow{2}{*}{ Sig. (2-tailed) } & \multirow{2}{*}{ Mean Difference } & \multicolumn{2}{|c|}{$95 \%$ Confidence Interval of the Difference } \\
\hline & & & & & Lower & Upper \\
\hline CAR TARGET $(-2,+2)$ & 10,753 & 160 & , 000 & ,14186121 & 11580681 & 16791561 \\
\hline CAR ACQUIRER $(-2,+2)$ &, 026 & 160 & 979 & ,00011072 &,- 00825176 & 00847320 \\
\hline
\end{tabular}

Table 8.

\begin{tabular}{|c|c|c|c|c|c|c|}
\hline \multicolumn{7}{|c|}{ One-Sample Test ${ }^{a}$} \\
\hline & \multicolumn{6}{|c|}{ Test Value $=0$} \\
\hline & \multirow{2}{*}{$\mathrm{t}$} & \multirow{2}{*}{ df } & \multirow{2}{*}{ Sig. (2-tailed) } & \multirow{2}{*}{ Mean Difference } & \multicolumn{2}{|c|}{ 95\% Confidence Interval of the Difference } \\
\hline & & & & & Lower & Upper \\
\hline CAR TARGET $(-2,+2)$ & 6,562 & 67 & 000 & , 16581843 & ,11537763 & 21625923 \\
\hline CAR ACQUIRER $(-2,+2)$ & $-2,130$ & 67 & 037 &,- 01418519 &,- 02747680 &,- 00089358 \\
\hline
\end{tabular}

The results of the model can also be analysed from another viewpoint. In particular, the average CARs and the respective significances are shown below, after segmenting the sample according to whether the observations correspond to deals with the assistance of first-tier banks or not (Table 11 and Table 12). On average, the targets assisted by first-tier investment banks show a better performance. More specifically, the abnormal cumulative average return for the targets goes respectively from $13.56 \%$, without a top advisor, to $16.79 \%$ when there is at least one top advisor (always with a p-value equal to 0.000 ). On the buy-side, instead, the p-values obtained are always above the significance threshold of 5\%. However, within the limits, we can consider the CARs of the bidders which are not assisted by a top advisor, where the p-value is only slightly above the $5 \%$ threshold. In this case, the cumulative abnormal return is negative and equal to $-0.93 \%$ (with a p-value of 0.051 ). Lastly, although without significance statistically, it can only be noted indicatively that the CAR is on average positive in the case of the presence of a first tier investment bank (Table 12) and otherwise negative and statistically significant (Table 11). The result according to which the cumulative abnormal returns are on average negative for acquirers which do not take avail of a top advisor is in contrast with Srinivasan (1999), who expresses opposite considerations, although in agreement with many other studies present in literature. On the other hand, unfortunately, the p-value does not allow for making significant considerations on the opposite scenario. 
Table 9.

\begin{tabular}{|c|c|c|c|c|c|c|}
\hline \multicolumn{7}{|c|}{ One-Sample Test ${ }^{a}$} \\
\hline & \multicolumn{6}{|c|}{ Test Value $=0$} \\
\hline & \multirow{2}{*}{$\mathrm{t}$} & \multirow{2}{*}{ df } & \multirow{2}{*}{ Sig. (2-tailed) } & \multirow{2}{*}{ Mean Difference } & \multicolumn{2}{|c|}{$\begin{array}{l}\text { 95\% Confidence Interval of the } \\
\text { Difference }\end{array}$} \\
\hline & & & & & Lower & Upper \\
\hline CAR TARGET $(-2,+2)$ & 8,980 & 133 & ,000 & 13557840 & ,10571583 & 16544096 \\
\hline CAR ACQUIRER $(-2,+2)$ & $-1,968$ & 123 & 051 & -00933339 & -01872158 & 00005480 \\
\hline
\end{tabular}

Table 10.

One-Sample Test ${ }^{\mathrm{a}}$

\begin{tabular}{|c|c|c|c|c|c|c|}
\hline & \multicolumn{6}{|c|}{ Test Value $=0$} \\
\hline & \multirow{2}{*}{$\mathrm{t}$} & \multirow{2}{*}{ df } & \multirow{2}{*}{ Sig. (2-tailed) } & \multirow{2}{*}{ Mean Difference } & \multicolumn{2}{|c|}{$\begin{array}{l}\text { 95\% Confidence Interval of the } \\
\text { Difference }\end{array}$} \\
\hline & & & & & Lower & Upper \\
\hline CAR TARGET $(-2,+2)$ & 8,732 & 94 &, 000 & 16787161 & ,12970203 & ,20604119 \\
\hline CAR ACQUIRER $(-2,+2)$ & 369 & 104 & ,390 & 00455561 &,- 00591678 & 01502801 \\
\hline
\end{tabular}

a. RANKING FIRST TIER (1) SECOND TIER (0) ADVISOR $=1$

However, these single-varied comparisons can be misleading, since they do not take into consideration any other variable except the advisor's reputation. As can be seen in the section on the description of the sample, for example, it comes to light that the top tier advisors are used for the larger sized transactions. Therefore, both firm-specific and deal-specific variables must be taken into consideration in order to check the effective influence of the "reputation" variable on the variable of our interest (the abnormal return). To this regard, multi-varied standard regression models have been developed (see the next section).

\subsection{The Regression Models}

The relationships between the advisor's reputation, the bidders' CARs and the acquirers' CARs, are examined below by means of regression models (Note 20). A central point of the analysis consists in comparing the models obtained for targets and for acquirers. With regard to the dependent variable, it was decided to use the CARs, expressed in percentage form, calculated over a time horizon of five days, corresponding to the event window $(-2,+2)$ (Ismail, 2010; Golubov et al., 2012). With regard to the independent variables, it may be noted that in all regression models the same independent variables have been included both for the analysis concerning the targets and for the analysis regarding the acquirer companies. This choice was made to render the analysis more homogeneous and to test the variable of the bank's/advisor's reputation, which is hypothesised as significant regardless of whether the analysis is made on the targets or on the acquirers. The independent variables considered are illustrated below:

- TOP-TIER: this is the variable of greatest interest for the research. It is a dummy variable which assumes a value of one when an investment bank, which has assisted a 
company in a transaction included in the sample, is placed within the first ten positions of the investment bank classification. It can be noted that when more than one bank participates in the same transaction, the variable assumes a value equal to one unit if at least one of the banks falls within the definition of a first tier investment bank;

- SAME INDUSTRY: this is a dummy variable which takes on the value of one when target and bidder are involved in a particular special financing operation and when they both operate in the same macro sector (Morck, Shleifer, and Vishny, 1990; Berger and Ofek, 1995);

- CROSS-BORDER: this is a dummy variable which takes on a value of one when target and bidder are not located in the same country (Allen et al., 2004; Doukas and Travlos,1988; Kang, 1993);

- TOT ADVISORS: variable which corresponds to the total number of investment banks which are involved in the operation assisting either target or acquirer (Iannotta 2010);

- DEAL VALUE: the value of the transaction. This is a continuous variable. Like the preceding variable, the deal value can also indicate the complexity of the operation. Transactions of relatively greater dimensions are considered by literature as more complex;

- TOEHOLD: this variable is a dummy which assumes a value of one when the acquirer already holds at least $5 \%$ of the target before the acquisition of a controlling stake (Ismail, 2010);

- TOP vs NOT: this variable, the only one which assumes different values according to whether the model refers to the behaviour of the target rather than the acquirer, is a dummy variable which is given the value of one when one of the counterparties has at least one top tier advisor while the other has only second tier advisors. When both counterparties have at least one first tier advisor, the variable is given the value of zero.

- RELATIVE SIZE: this is the ratio of the total assets of the target to the total assets of the bidder (Rajan, Servaes, and Zingales, 2000);

- CASH: this is a dummy variable given the value of one when the payment does not include shares (Travlos,1987; Ismail, 2010). The reaction of the market is therefore considered better in the case of payments in cash. One explanation is that cash deals are usually associated with the issue of debt, which is an incentive for the management to be more disciplined;

- STOCK: a variable dummy which takes on the value of one when the acquisition is carried out by means of a share swap (Ismail,2010; Iannotta 2010).

\subsubsection{The Results}

For both types of companies involved in a merger or a takeover, verification was carried out as to whether the creation of value, at the announcement of the M\&A operation, was linked to the reputation of the investment bank acting as advisor for the deal and how this phenomenon varies between the period before (Note 21) and after (Note 22) the Lehman Brothers bankruptcy. The proxy of the considered creation of value, the dependent variable, 
corresponds to the cumulative abnormal returns (CARs), calculated according to the market model methodology, over a time window of five days (Ismail, 2010; Golubov et al., 2012).

\subsubsection{The Results for the Target}

The regression model corresponding to the pre-Lehman crash period (Figure 1) is composed of 161 observations and 10 independent variables. The R2 of $15.7 \%$ and the model as a whole is highly significant. The test $\mathrm{F}$, which measures a bond between all the variables selected and the dependent variable has an associated p-value of almost zero (0.003). Analysing the significance of the variables, it can be observed that only three of the ten variables considered are significant. They are the variables STOCK, TOEHOLD and CROSS-BORDER, respectively significant at $1 \%$, at $5 \%$ and, within the limits of acceptability, at $10 \%$. The negative coefficient of the STOCK variable, in line with Ismail (2010), indicates that acquisitions financed by shares result in lower returns for the shareholders of the company acquired. The negative coefficient of the dummy variable TOEHOLD indicates that the presence of a toehold, i.e. already owning some of the equity of the target company, reinforces the buyer company's position in the negotiating phase. This can depend on the fact that the toehold, favouring a greater availability of information, reduces possible problems of information asymmetries and allows the buyer to reach a better and more correct evaluation of the target.

\begin{tabular}{|c|c|c|c|}
\hline \multicolumn{4}{|l|}{ Model Summary } \\
\hline $\mathrm{R}$ & $\mathrm{R}$ Square & Adjusted R Square & Std. Error of the Estimate \\
\hline, 396 &, 157 &, 101 &, 15872629 \\
\hline
\end{tabular}

\begin{tabular}{|c|c|c|c|c|c|}
\hline \multicolumn{7}{|l|}{ ANOVA } & Sum of Squares & df & Mean Square & F & Sig. \\
\hline Regression &, 704 & 10 &, 070 & 2,796 &, 003 \\
\hline Residual & 3,779 & 150 &, 025 & & \\
\hline Total & 4,483 & 160 & & & \\
\hline
\end{tabular}

\begin{tabular}{|c|c|c|c|c|c|c|c|}
\hline \multicolumn{8}{|l|}{ Coefficients } \\
\hline \multirow[t]{2}{*}{ Model } & \multicolumn{2}{|c|}{$\begin{array}{c}\text { Unstandardized } \\
\text { Coefficients }\end{array}$} & \multirow{2}{*}{$\begin{array}{c}\text { Standardized } \\
\text { Coefficients } \\
\text { Beta }\end{array}$} & \multirow[t]{2}{*}{$\mathrm{t}$} & \multirow[t]{2}{*}{ Sig. } & \multicolumn{2}{|c|}{ Collinearity Statistics } \\
\hline & B & Std. Error & & & & & B \\
\hline (CONSTANT) &, 177 &, 046 & & 3,807 &, 000 & (CONSTANT) &, 177 \\
\hline TOP-TIER &,- 002 &, 033 &,- 006 &,- 059 & ,953 & TOP-TIER &,- 002 \\
\hline SAME INDUSTRY &, 001 &, 027 &, 004 &, 047 & ,963 & SAME INDUSTRY &, 001 \\
\hline CROSS-BORDER &, 049 &, 027 &, 140 & 1,773 &, 078 & CROSS-BORDER &, 049 \\
\hline TOEHOLD &,- 075 &, 037 &,- 162 & $-2,016$ &, 046 & TOEHOLD &,- 075 \\
\hline DEAL VALUE &, 000 &, 000 &,- 007 &,- 078 & ,938 & DEAL VALUE &, 000 \\
\hline TOT ADVISORS &,- 002 &, 009 &,- 020 &,- 219 &, 827 & TOT ADVISORS &,- 002 \\
\hline RELATIVE SIZE & ,006 &, 012 &, 042 &, 522 & 602 & RELATIVE SIZE & ,006 \\
\hline
\end{tabular}




\begin{tabular}{|c|c|c|c|c|c|c|c|}
\hline STOCK &,- 109 &, 040 &,- 314 & $-2,755$ &, 007 & STOCK &,- 109 \\
\hline CASH &, 002 &, 038 &, 005 &, 042 &, 967 & CASH &, 002 \\
\hline TOP vs NOT &, 002 &, 043 &, 003 &, 038 &, 970 & TOP vs NOT &, 002 \\
\hline
\end{tabular}

Figure 1. Car target: the regression model corresponding to the pre-Lehman crash period

Lastly, it must also be pointed out that the multi-varied regression relative to the time frame prior to the Lehman collapse shows no evidence indicating that the identity and reputation of the investment bank is an important variable in determining the market reaction and the consequent creation of value for the target on the announcement of M\&A operations. However, the results of the post Lehman regression model (Figure 2) (Note 23) are different, and in fact show an inverse scenario. Above all, it is to be noted that the R2 considerably improves, reaching $28.1 \%$. And it can be noted that with the increase in the R2, so the adjusted R2 also increases, albeit to a lesser extent, from $10.1 \%$ to $15.5 \%$. Considering that the number of the variables does not change, the less than proportional increase of the R2 could derive from the fewer observations on which the new model is based (the sample relative to the post-bankruptcy period is, in fact, composed of only 68 subjects). The p-value associated to the test $\mathrm{F}$ worsens slightly but it nevertheless remains below the $5 \%$ threshold. Having said this, it is important to underline that in this new scenario the model indicates a strongly positive and significant effect of the investment bank's reputation (the advisor's reputation) on the cumulative abnormal returns (CARs) of the target. More specifically, with an error probability of $0.4 \%$ (p-value associated to the t-test equal to 0.004 ), the coefficient of the TOP-TIER variable indicates that the presence of at least one top tier bank among the target's $2 d v i s o r s$ contributes to increasing the wealth of the latter's shareholders by about $22.7 \%$ (Note 24). With reference to the same time window as that considered in the regression model, the targets assisted by a top investment bank obtain average cumulative returns of $25.47 \%$ (about $12.6 \%$ more than the average CARs without at least one top advisor).

\begin{tabular}{|c|c|c|c|}
\hline \multicolumn{4}{|l|}{ Model Summary } \\
\hline $\mathrm{R}$ & R Square & Adjusted R Square & Std. Error of the Estimate \\
\hline, 530 &, 281 &, 155 &, 19156828 \\
\hline
\end{tabular}

\begin{tabular}{|c|c|c|c|c|c|}
\hline \multicolumn{7}{|l|}{ ANOVA } & Sum of Squares & df & Mean Square & F & Sig. \\
\hline Regression &, 819 & 10 &, 082 & 2,230 &, 028 \\
\hline Residual & 2,092 & 57 &, 037 & & \\
\hline Total & 2,910 & 67 & & & \\
\hline
\end{tabular}

\begin{tabular}{|c|c|c|c|c|c|}
\hline \multicolumn{1}{|l|}{ Coefficients } \\
\hline Model & Unstandardized Coefficients & $\begin{array}{c}\text { Standardized } \\
\text { Coefficients }\end{array}$ & $\mathrm{t}$ & Sig. & $\begin{array}{c}\text { Collinearity } \\
\text { Statistics }\end{array}$ \\
\hline
\end{tabular}




\section{Macrothink}

International Finance and Banking

ISSN 2374-2089

2014, Vol. 1, No. 2

\begin{tabular}{|c|c|c|c|c|c|c|c|}
\hline & B & Std. Error & Beta & & & Tolerance & VIF \\
\hline (Constant) &, 388 &, 109 & & 3,553 &, 001 & & \\
\hline Top-Tier & ,227 & ,076 &, 500 & 2,975 & ,004 & ,447 & 2,238 \\
\hline Same Industry &,- 087 & ,059 &,- 179 & $-1,485$ &, 143 &, 870 & 1,149 \\
\hline Cross-Border &, 057 & ,059 &, 118 & ,957 & ,343 &, 823 & 1,215 \\
\hline Toehold &,- 031 &, 062 &,- 062 &,- 501 &, 618 &, 816 & 1,225 \\
\hline Deal Value &, 000 & ,000 &,- 225 & $-1,677$ & ,099 & ,700 & 1,428 \\
\hline Tot Advisors &,- 041 &, 021 &,- 266 & $-1,957$ &, 055 & ,684 & 1,463 \\
\hline Relative Size &,- 016 &, 007 &,- 275 & $-2,209$ & ,031 &, 814 & 1,229 \\
\hline Stock &,- 015 & ,079 &,- 037 &,- 194 &, 847 &, 355 & 2,814 \\
\hline Cash &,- 107 & ,081 &,- 258 & $-1,317$ & ,193 & ,329 & 3,038 \\
\hline Top Vs Not &,- 002 & , 109 &,- 002 &,- 017 & ,987 & ,673 & 1,486 \\
\hline
\end{tabular}

Figure 2. Car target: the regression model corresponding to the post-Lehman crash period

The top banks often push their customers towards acquisitions that may even be far from the rational grounds (on which decisions regarding M\&A should be based), just to earn fees. The analysis shows that the certification effect guaranteed by the investment banks (especially by those with an extremely high reputation) was not effective in the case of the more recent wave of M\&As.

Reviewing the other variables, it can be observed that the relative size coefficient concerning the relative dimensions of the target is at a significant minus 5\%: the operations for the acquisition of control and/or the integration of a target which is relatively large compared to the acquirer are more complex and lead to the creation of less value. Similarly, the negative coefficient of the variable linked to the total number of advisors involved in the operation, although barely above the significance threshold of 5\%, indicates that the more advisors there are around the negotiating table, the less value will be created. The presence of a high number of investment banks can depend on a greater complexity of the deal, which results in a greater difficulty to release value through the operation. Lastly, although border line in respect of a significance value of $10 \%$, it can be noted that the DEAL VALUE variable has a zero coefficient. Which means that the size of an operation has no impact on the creation of value for the shareholders.

\subsubsection{The Results for the Acquirer}

As in the case of the analysis of the targets, also for the buyer companies it can be noted that there are two very different results depending on whether model refers to the pre or post Lehman crash period. More specifically, the model relative to the pre-bankruptcy period (Figure 3), as a whole, is not significant. The test $\mathrm{F}$ on the joint significance of the coefficients of the regression is equal to 1,832 , with an associated p-value equal to 0.06 (Note 25). Similarly to the scenario observed for the targets, also in the case of the acquirer, the multi-varied regression model suggests that the advisor's reputation is an extremely important fact influencing the creation of value for the shareholders. 
Model Summary

\begin{tabular}{|c|c|c|c|}
\hline $\mathrm{R}$ & $\mathrm{R}$ Square & Adjusted R Square & Std. Error of the Estimate \\
\hline, 330 &, 109 &, 049 &, 05238423 \\
\hline
\end{tabular}

\begin{tabular}{|c|c|c|c|c|c|}
\hline \multicolumn{7}{|l|}{ ANOVA } & Sum of Squares & df & Mean Square & F & Sig. \\
\hline Model &, 050 & 10 &, 005 & 1,832 &, 060 \\
\hline Regression &, 412 & 150 &, 003 & & \\
\hline Residual &, 462 & 160 & & & \\
\hline Total & & & & \\
\hline
\end{tabular}

\begin{tabular}{|c|c|c|c|c|c|c|c|}
\hline \multicolumn{8}{|l|}{ Coefficients } \\
\hline \multirow{3}{*}{ Model } & \multirow{2}{*}{\multicolumn{2}{|c|}{$\begin{array}{c}\text { Unstandardized } \\
\text { Coefficients }\end{array}$}} & \multirow{3}{*}{$\begin{array}{c}\begin{array}{c}\text { Standardized } \\
\text { Coefficients }\end{array} \\
\text { Beta }\end{array}$} & \multirow{3}{*}{$\mathrm{t}$} & \multirow{3}{*}{ Sig. } & \multirow{2}{*}{\multicolumn{2}{|c|}{ Collinearity Statistics }} \\
\hline & & & & & & & \\
\hline & $\mathrm{B}$ & Std. Error & & & & & B \\
\hline (Constant) &,- 020 & ,016 & & $-1,270$ & ,206 & (Constant) &,- 020 \\
\hline Top-Tier &,- 012 & 011 &,- 110 & $-1,074$ & ,285 & Top-Tier &,- 012 \\
\hline Same Industry &,- 002 &, 009 &,- 013 &,- 169 &, 866 & Same Industry &,- 002 \\
\hline Cross-Border & ,000 & ,009 &, 000 &,- 006 & ,996 & Cross-Border &, 000 \\
\hline Toehold & ,020 & 012 & , 138 & 1,676 & ,096 & Toehold & ,020 \\
\hline Deal Value & ,000 &, 000 &, 036 & ,369 & ,713 & Deal Value &, 000 \\
\hline Tot Advisors &, 005 &, 003 &, 167 & 1,740 &, 084 & Tot Advisors &, 005 \\
\hline Relative Size &,- 001 &, 004 &,- 030 &,- 369 &, 713 & Relative Size &,- 001 \\
\hline Cash &, 016 &, 012 &, 150 & 1,296 & ,197 & Cash &, 016 \\
\hline Stock &,- 010 &, 013 &,- 089 &,- 750 &, 454 & Stock &,- 010 \\
\hline Top vs Not & 020 &, 014 & ,137 & 1,449 & ,149 & Top vs Not &, 020 \\
\hline
\end{tabular}

Figure 3. Car Acquirer: the regression model corresponding to the pre-Lelhman crash period

As for the model relative to the targets, therefore, also in the case of the pre-Lehman acquirers, no empiric evidence can be found to indicate that the reputation of the advisors plays an important role in determining the creation of value for the shareholders. For that matter, the result is also confirmed by the t-test carried out on the CARs involving the segmentation of the sample in respect of both the period and the presence or absence of an advisor (Note 26). Returning to the model, within the limits of significance, it is possible to note the positive sign of the coefficient of the TOEHOLD variable. Contrary to what happens for the targets, the buyer companies benefit from a toehold in the equity of the companies that they wish to takeover. The existence of a toehold, of at least $5 \%$, in the equity of the target results in a CAR, for the acquirer's shareholders, of more than two percentage points. The output relative to the post-crash period (Figure 4), however, takes on particular importance. Compared to the previous model, in this case both the R2 and the adjusted R2 increase considerably and take on important values. In particular, R2 increases from $10.9 \%$ to $38.0 \%$ 
while the adjusted R2 increases from $4.9 \%$ to $27.2 \%$. Furthermore, the model, as a whole, is associated with a p-value below the $1 \%$ threshold. In addition, the positive and significant coefficient (with an associated p-value of 0.032 ) of the TOP-TIER variable, which, of all the variables, is the one which assumes greater weight in the model, indicates that the advisors with a higher reputation (a greater market share) bring a benefit to the shareholders, in CAR terms, of $4.4 \%$. Consistently with the literature, which attributes to the targets the greater part of the benefits of an operation, it is not surprising that the creation of value for the bidder, taking avail of a primary investment bank, is considerably lower than that of the target. As pointed out for the targets, therefore, also in the case of post-Lehman bidders, the shareholders' wealth is positively influenced by the engagement of a top investment bank (Note 27).

\begin{tabular}{|c|c|c|c|}
\hline \multicolumn{4}{|l|}{ Model Summary } \\
\hline $\mathrm{R}$ & $\mathrm{R}$ Square & Adjusted R Square & Std. Error of the Estimate \\
\hline, 617 &, 380 &, 272 &, 04563309 \\
\hline
\end{tabular}

\begin{tabular}{|c|c|c|c|c|c|}
\hline ANOVA & Sum of Squares & df & Mean Square & F & Sig. \\
\hline Regression &, 073 & 10 &, 007 & 3,501 &, 001 \\
\hline Residual &, 119 & 57 &, 002 & & \\
\hline Total &, 192 & 67 & & & \\
\hline
\end{tabular}

\begin{tabular}{|c|c|c|c|c|c|c|c|}
\hline \multicolumn{8}{|l|}{ Coefficients } \\
\hline \multirow[t]{2}{*}{ Model } & \multicolumn{2}{|c|}{$\begin{array}{c}\text { Unstandardized } \\
\text { Coefficients }\end{array}$} & \multirow{2}{*}{$\begin{array}{c}\begin{array}{c}\text { Standardized } \\
\text { Coefficients }\end{array} \\
\text { Beta }\end{array}$} & \multirow[t]{2}{*}{$\mathrm{t}$} & \multirow[t]{2}{*}{ Sig. } & \multicolumn{2}{|c|}{ Collinearity Statistics } \\
\hline & B & Std. Error & & & & & B \\
\hline (Constant) & ,008 & 026 & & 294 &, 770 & (Constant) & ,008 \\
\hline Top-Tier & ,044 & ,020 & ,413 & 2,194 &, 032 & Top-Tier &, 044 \\
\hline Same Industry &,- 035 &, 014 &,- 280 & $-2,532$ &, 014 & Same Industry &,- 035 \\
\hline Cross-Border & ,012 & 015 &, 098 & 812 &, 420 & Cross-Border &, 012 \\
\hline Toehold &,- 009 &, 015 &,- 073 &,- 629 &, 532 & Toehold &,- 009 \\
\hline Deal Value & 000 &, 000 &, 052 &, 420 & 676 & Deal Value & ,000 \\
\hline Tot Advisors &,- 009 &, 005 &,- 217 & $-1,654$ &, 104 & Tot Advisors &,- 009 \\
\hline Relative Size &,- 006 &, 002 &,- 412 & $-3,556$ &, 001 & Relative Size &,- 006 \\
\hline Cash &, 027 & 019 & ,253 & 1,398 &, 167 & Cash &, 027 \\
\hline Stock & ,032 & 019 & ,301 & 1,716 & ,092 & Stock &, 032 \\
\hline Top Vs Not &,- 026 & ,019 &,- 201 & $-1,389$ &, 170 & Top Vs Not &,- 026 \\
\hline
\end{tabular}

Figure 4. Car Acquirer: the regression model corresponding to the post-Lehman crash period 
However, looking at the coefficients of the other variables which result as significant, the negative coefficient of the SAME INDUSTRY variable is quite surprising, while in preceding literature (Morck et al.,1990; Berger and Ofek, 1995) it was shown that the creation of value for the buyer company is greater in cases in which the target operates in a business connected to that of the said buyer. But in the model in question, an acquisition carried out within the same sector would lead to a reduction of value for the shareholders equal to $3.5 \%$. This evidence supports the hypothesis of the creation of value by corporate diversification. Furthermore, with regard to the STOCK variable, although with a high p-value, almost reaching the $10 \%$ threshold, the positive coefficient of this variable indicates that the buyer companies, unlike the seller companies, benefit from payment in the form of shares. This result is understandable, if one considers that the bidders usually offer payment in the form of shares when they believe that their own shares are over-valued on the market (it is to be noted that this subject is discussed in the literature with regard to the informative asymmetries) (Note 28).

\section{Conclusions}

Starting from the empiric evidence in literature, concerning the role of investment banks in M\&A operations, the capacity of the investment banks with the best reputation to offer their customers services of a superior quality, corresponding to the creation of greater value for the shareholders, was questioned. The study focussed on the transactions carried out only between listed companies and on the use of analysis relative to two time frames which were symmetrical to each other in respect of the Lehman Brothers bankruptcy. The analysis brought to light that, post Lehman, the top tier investment banks are associated with higher returns for the shareholders of both target companies and buyer companies, thus supporting the "superior deal hypothesis". However, this evidence can be found only in the "post financial crisis" period (post-Lehman), while the assistance of an investment bank with a better reputation is not significantly associated to the creation of higher value in the period prior to the Lehman collapse. It must also be noted that the term "financial crisis" is used to refer to a concept which can hardly be defined in terms of space and time; the research wished to express the idea of a different economic/financial context, identifying the Lehman Brothers bankruptcy as the signal which started off a period featuring deep changes of a structural nature, above all in the investment banking sector. The certification effect of the investment banks, within the sphere of M\&A operations, has therefore been found to have no significance in the pre-Lehman crash period. However, this result is comprehensible if one considers the irrationality which prevailed at the time of the more recent wave of M\&A operations. The number of deals processed and the positive sentiment which featured the capital markets in the years prior to the explosion of the crisis, easily supports the idea that in such a context the advisor's reputation and the certification of the deals provided by the same were of little importance. The irrational attitude of the pre-crash period is confirmed by the change of market behaviour after the start of the financial crisis. The more careful, more rational market has given greater importance to and has placed greater confidence in the banking institutions which, before and after the crisis, have demonstrated that they have maintained a high reputation, succeeding in managing the corporate control market. In a time 
of crisis, therefore, the capacity of the top tier investment banks to construct better operations, has allowed for generating greater synergies and benefits for their customer companies, with consequent growth in value for the shareholders of the same. Furthermore, the results, at least as far as concerning the more recent period, confirm the thesis (Chemmanur and Fulghieri,1994) according to which the top tier banks are superior in processing and producing information which can reduce the information asymmetries between the diverse players on the market. Thus, the higher the banks reputation and credibility, the greater the certification and validation effect of the deal supplied by the same.

\section{References}

Allen, F. (1984). Reputation and product quality. The Rand Journal of Economics, 15(3), 311-327.

Allen, F., Brealey, R. A., Myers, S. C., \& Sandri, S. (2007). Principi di finanza aziendale (5th ed.). Milan: McGraw-Hill.

Allen, L., Jagtiani, J., Peristiani, S., \& Saunders, A. (2004). The role of bank advisor in mergers and acquisitions. Journal of Money, Credit, and Banking, 36(2), 197-224.

Bao, J., \& Edmans, A. (2011). Do investment banks matter for M\&A returns? The Review of Financial Studies, 24(7), 2286-2315.

Berger, P. G., \& Ofek, E. (1995). Diversification's effect on firm value. Journal of Financial Economics, 37(1), 39-65.

Binder, J. J. (1998). The event study methodology since 1969. Review of Quantitative Finance and Accounting, 11, 111-137.

Bowers, H. M., \& Miller, R. E. (1990). Choice of investment banker and shareholders' wealth of firms involved in acquisitions. Financial Management, 19(4), 34-44.

Bradley, M. (1980). Inter-firm tender offers and the market for corporate control. Journal of Business, 37, 39-65.

Brown, S. J., \& Warner, J. B. (1980). Measuring security price performance. Journal of Financial Economics, 8, 205-258.

Brown, S. J., \& Warner, J. B. (1985). Using daily stock returns: the case of event studies. Journal of Financial Economics, 14, 3-31.

Buongiorno, M., \& Conca, V. (2007). I servizi di advisory a supporto delle operazioni di M\&A: contenuti, attori e trend di mercato. In V. Capizzi (Ed.), L'investment banking in Italia (pp. 171-198). Rome: Bancaria Editrice.

Capizzi, V. (2007a). Gli intermediari finanziari e i servizi a supporto delle acquisizioni aziendali. In G. Forestieri (Ed.), Corporate e investment banking (4th ed., pp. 345-387). Milan: Egea.

Capizzi, V. (2007b). Il settore dei servizi di investment banking in Italia: confini, dimensione 
e trend di mercato. In V. Capizzi (Ed.), L'investment banking in Italia (pp. 21-86). Rome: Bancaria Editrice.

Capizzi, V. (2007c). L'investment banking in Italia. Rome: Bancaria Editrice.

Capizzi, V., \& Giovannini, R. (2010). Investment banking services: ownership structures, financial advisory and corporate governance models. International Journal of Business Administration, 1(1), 49-63.

Carter, R., Dark, F., \& Singh, A. (1998), Underwriter reputation, initial returns, and the long-run performance of IPO stocks. Journal of Finance, 53, 285-311.

Carter, R., \& Manaster, S. (1990). Initial Public Offerings and underwriter reputation. The Journal of Finance, 45(4), 1045-1067.

Chemmanur, T. J., \& Fulghieri, P. (1994). Investment bank reputation, information production, and financial intermediation. The Journal of Finance, XLIX(1), 57-79.

Davidson, W. N., Dutia, D., \& Cheng, L. (1989). A re-examination of the market reaction to failed mergers. Journal of Finance, 44(4), 1077-1084.

Dyckman, T., Philbrick, D., \& Stephan, J. (1984). A comparison of event studies methodologies using daily stock returns: a simulation approach. Journal of Accounting Research, 22, 1-30.

Doukas, J., \& Travlos, N. G. (1988). The effect of corporate multinationalism on shareholders' wealth: evidence from international acquisitions. The Journal of Finance, 43(5), 1161-1175.

Fama, E. (1970). Efficient capital markets: a review of theory and empirical work. Journal of Finance, 25, 383-417.

Forestieri, G. (2011). Corporate e investment banking (2nd ed.). Milan: Egea.

Fuller, K., Netter, J., \& Mike, S. (2002). What do returns to acquiring firms tell us? Evidence from firms that make many acquisitions. The Journal of Finance, LVII(4), 1763-1793.

Gaughan, P. A. (2011). Mergers, acquisitions and corporate restructurings (5th ed.). New Jersey: Wiley.

Golubov, A., Petmezas, D., \& Travlos, N. G. (2012). When it pays to pay your investment banker: new evidence on the role of financial advisors in M\&As. Journall of Finance, 63(1), 271-312.

Halpern, P. (1983). Corporate acquisitions: a theory of special cases? A review of event studies applied to acquisitions. Journal of Finance, 38(2), 297-317.

Harris, R. J. (1985). A primer of multivariate statistics (2nd ed.). New York: Academic Press.

Huang, Y. S., \& Walkling, R. A. (1987). Target abnormal returns associated with acquisition announcements: payment, acquisition form, and managerial resistance. Journal of Financial Economics, 19, 329-349. 
Hunter, W. C., \& Walker, M. B. (1990). An empirical examination of investment banking merger fee contracts. Southern Economic Journal, 56, 1117-1130.

Iannotta, G. (2010). Investment banking: a guide to underwriting and advisory services. London, New York: Springer.

Ismail, A. (2008). Which acquirers gain more, single or multiple? Recent evidence from the USA market. Global Finance Journal, 19, 72-84.

Ismail, A. (2010). Are good financial advisors really good? The performance of investment banks in the M\&A market. Review of Quantitative Finance and Accounting, 35, 411-429.

Kale, J. R., Kini, O., \& Ryan, H. E. (2003). Financial advisors and shareholder wealth gains in corporate takeovers. Journal of Finance and Quantitative Analysis, 38(3), 475-501.

Kang, J. K. (1993). The international market for corporate control-mergers and acquisitions of U.S. firms by Japanese firms. Journal of Financial Economics, 34(3), 345-371.

Keown, A. J., \& Pinkerton, J. M. (1981). Merger announcements and insider trading activity: an empirical investigation. Journal of Finance, 36(4), 855-869.

Klein, B., \& Leffler, K. B. (1981). The role of market forces in assuring contractual performance. Journal of Political Economy, 89(4), 615-641.

Kothari, S. P., \& Warner, J. B. (2007). Econometrics of event studies. Handbook of Corporate Finance: Empirical Corporate Finance, 1, 3-36.

Lane, W. R., Wansley, J. W., \& Yang, H. C. (1983). Abnormal returns to acquired firms by type of acquisition and method of payment. Financial Management, 12(3), 16-22.

Ma, Q. (2006). Merger and investment banks: how do banks help targets? Working Paper. University of South California-Marshall School of Business, CA, USA.

Martynova, M., \& Renneboog, L. (2006). Mergers and acquisitions in Europe. Working Paper. Tilburg University, Holland.

McLaughlin, R. M. (1990). Investment-banking contracts in tender offers: an empirical analysis. Journal of Financial Economics, 28, 209-232.

McLaughlin, R. M. (1992). Does the form of compensation matter? Journal of Financial Economics, 32, 223-260.

Megginson, W. L., \& Weiss, K. A. (1991). Venture capitalist certification in Initial Public Offerings. The Journal of Finance, 46(3), 879-903.

Michel, A., Shaked, I., \& Lee, Y. (1991). An evaluation of investment banker acquisition advice: the shareholders' perspective. Financial Management, 20, 40-49.

Morck, R., Shleifer, A., \& Vishny, R. W. (1990). Do managerial objectives drive bad acquisitions?. The Journal of Finance, 45(1), 31-48.

Panaydes, P. M., \& Gong, X. (2002). The stock market reaction to merger and acquisition 
announcements in liner shipping. International Journal of Maritime Economics, 4(1), 55-80.

Pettit, R., Seth, A., \& Song, K. P. (2000). Sinergy, managerialism or hubris? An empirical examination of motives of foreign acquisitions of U.S. firms. Journal of International Business Studies, 31(3), 387-405.

Puri, M. (1996). Commercial banks in investment banking: conflict of interest or certification role? Journal of Financial Economics, 46, 373-401.

Rasedie, K., \& Srinivasan, G. (2011). Investment bank market share and the performance of acquiring companies: Canadian evidence. Journal of Comparative International Management, 14(1), 26-51.

Rau, P. R. (2000). Investment bank market share, contingent fee payments, and the performance of acquiring firms. Journal of Financial Economics, 56, 293-324.

Rau, P. R., \& Rodgers, K. J. (2002). Do bidders hire top-tier investment banks to certify value? Working Paper. Purdue University, IND, USA.

Rajan, R., Servaes, H., \& Zingales, L. (2000). The cost of diversity:the diversification discount and inefficient investment. Journal of Finance, 55(1), 35-80.

Ravenscraft, D. J., \& Scherer, F. M. (1987). Mergers, sell-offs and economic efficiency. Berkeley, CA: The Brookings Institution.

Rhee, M., \& Valdez, M. E. (2009). Contextual factors surrounding reputation damage with potential implications for reputation repair. Academy of Management Review, 34, 146-168.

Roll, R. (1986). The hubris hypothesis of corporate takeovers. Journal of Business, 59(2), 197-216.

Saunders, A., \& Srinivasan, A. (2001). Investment banking relationships and merger fees. Working Paper, New York University, NY, USA.

Scholtens, B., \& Wensveen Van, D. (2003). The theory of financial intermediation: an essay on what it does (not) explain. Vienna, SUERF.

Servaes, H., \& Zenner, M. (1996). The role of investment banks in acquisitions. The Review of Financial Studies, 9(3), 787-815.

Shapiro, C. (1983). Premiums for high quality products as returns to reputations. The Quarterly Journal of Economics, 98(4), 659-679.

Song, W., \& Wei, J. D. (2012). The value of "boutique" financial advisors in mergers and acquisitions. Working Paper. University of Cincinnati, OH, USA.

Travlos, N. (1987). Corporate takeover bids, means of payment, and bidding firms stock returns. Journal of Finance, 42, 943-964.

Varaiya, N. (1988). The winner's curse hypothesis and corporate takeovers. Managerial and Decision Economics, 9, 209-219. 
Walter, S., Yawson, A., \& Yeung, C. (2008). The role of investment banks in M\&A transactions: fees and services. Pacific-Basin Finance Journal, 16, 341-369.

\section{Notes}

Note 1. Source: Thomson.

Note 2. Indicatively, the ten top investment banks in the world received about $50 \%$ of the total fees generated by the advisory services.

Note 3. This work does not take into consideration the dynamics relative to the fees applied by the investment banks.

Note 4. The "boutiques" are independent companies, of relatively smaller size than the traditional investment banks, and they focus on advisory services in specific sectors. They prefer operations of medium-small size and they are experienced and skilled in M\&A. A particular feature of these companies is that "they do not sustain the financial management and risks of activities in their own name" (Forestieri, 2011). The most important names include Lazard (at least until 2005, the year of its listing), Rothschild and, of the Italian boutiques, Banca Leonardo.

Note 5. Capizzi, V. (2007). Financial brokers and services in support of company acquisitions. In G. Forestieri (edited by) Corporate e investment banking, 4th edition, Milan, Egea: pp. 345-387.

Note 6. Allen et al. (2004) have examined in depth the aspects of the so-called certification effect and of the customer-consultant relationship, and they have extended them to the "role" of the investment banks in M\&A operations. .

Note 7. Important financial information providers, like Bloomberg or Thomson Reuters, which register and file in enormous databases the events on the financial markets, allow for obtaining, in a very simple way, ad hoc league tables for pre-determined time periods and specific geographic areas

Note 8. Source: Thomson Reuters SDC.

Note 9. Date on which Lehman Brothers was placed under bankruptcy protection.

Note 10. Megginson and Weiss (1991), in their work concerning IPO operations, considered the effective market share, while Bowers and Miller (1990) and Servaes and Zenner (1996), always on the basis of the market share, divided the banks into two groups: top tier (the first 5 banks1) and second tier (all the others) depending on the market share of the corporate control market in the period of the sample used. Rau (2000), instead, considered three reputation levels. Alternatively, Carter and Manaster (1990), specifically regarding IPO operations, deduced the reputation of the investment banks from their positions in the tombstones1 shown in the financial daily newspapers. Carter, Dark, and Singh (1998) have shown that the market share (understood as a continuous variable), the three-level 
classification and the classification deduced by the tombstones are closely linked as far as concerning the IPO market.

Note 11. The first-tier investment banks are those in the first ten positions, and the second-tier investment banks are all the other classified after the tenth position (Ismail, 2010). The terms first-tier and top-tier are used indistinctly in the work and have the same meaning.

Note 12. For informative purposes, the positions adopted by the various advisors in each year are shown, as reported by Thomson Reuters.

Note 13. The division according to the sector to which the companies belong has been based on the macro industry classification of Thomson Reuters. More specifically, following the terminology of the financial data provider, the companies of our sample are divided among eleven sectors: Energy and Power (ENERGY); Industrial (IND); High Technology (HT); Telecommunications (TELECOM); Retail (RETAIL); Healthcare (HEALTH); Media and Entertainment (MEDIA); Real Estate (REALEST); Materials (MATERLS); Consumer Products and Services (CPS); Consumer Staples (STAPLES).

Note 14. The choice of benchmark fell on the STOXX Europe 600 Index, a sub-group of the STOXX Global 1800 Index. With a fixed number of 600 components, the STOXX Europe 600 Index represents a series of companies with small, medium and large equities, located somewhere in the following 18 European countries: Austria, Belgium, Denmark, Finland, France, Germany, Greece, Ireland, Iceland, Italy, Luxembourg, Norway, Holland, Portugal, United Kingdom, Spain, Sweden and Switzerland (Source: www.stoxx.com). Furthermore, the choice of a benchmark which includes all the sectors also depends on the mixed nature of the sample of transactions considered, as emerging from the descriptive analysis.

Note 15 . The objection generally raised, when one decides to opt for this choice, is that the daily returns are not normal. The fact that the returns are distributed in a Gaussian manner is, in fact, at the basis of the event study methodology.

Note 16. For the application of this methodology, it is necessary to estimate the parameters through the ordinary least squares (OLS).

Note 17. It is important to note that the expected return on the shares has been estimated starting from a time frame of reference, used for the estimate of the parameters, which goes from 170 to 20 days before the event. A common mistake in studies of this type is to estimate the parameters through a regression including the date of the event and to then calculate the abnormal returns on the basis of those estimates. This non-rigorous method would underestimate the abnormal returns.

Note 18. This evidence derives from previous literature: Bradley (1980) shows that the market reaction can be perceived up to ten days before the communication to the public.

Note 19. The test was carried out using SPSS software.

Note 20. Multi-varied OLS.

Note 21. It may be remembered that the said four-year period goes from 15/09/2004 to 


\section{Macrothink}

15/09/2008, the day on which the Lehman Brothers bankruptcy procedure was opened.

Note 22. This time frame, always of 4 years, goes from $15 / 09 / 2008$, the day on which the Lehman Brothers bankruptcy procedure was opened, until 15/09/2012.

Note 23. The result confirms the analysis carried out on the CARs (Appendix "A": Table A-3 and Table A-4) relative to the post-bankruptcy time frame.

Note 24. The tables (Table A-3 and Table A-4) in the Appendix show that this phenomenon is also confirmed by the analysis of the CARs.

Note 25. It is not possible to link this phenomenon to a problem of the size of the sample compared to the relatively high number of predictors considered, since, as in the case of the targets, the historically accepted general rule is satisfied, according to which at least 10 subjects per predictor are required (Harris, 1985).

Note 26. Observing the tables in Appendix "A" (Table A-2 and Table A-3), it can be seen, in fact, that in spite of the change of sign in the average of the CARs in the presence of a top advisor, it is not possible to draw significant conclusions (in view of the very high p-value).

Note 27. This evidence is also supported by what emerges from the t-test on the CARs (Appendix "A": Table A-3 and Table A-4). The CARs of the bidders which take avail of a top investment banker in fact achieve a better performance.

Note 28. In Appendix B, the correlation matrices between the variables can be consulted. Lastly, to give further significance to the models, it is observed that the scatter plots of the residues of the regressions in Appendix "C" (Figure C-3 and Figure C4) show that there is no particular evidence of heteroscedasticity. The figures trace good behaviour of the residues: they are alternatively above and below zero and they are distributed in a non-systematic manner.

\section{Appendix}

Appendix 1. CARs and t-test

Table A1.

\begin{tabular}{|c|c|c|c|c|c|c|}
\hline \multicolumn{7}{|c|}{ One-Sample Test ${ }^{\mathrm{a}}$} \\
\hline & \multicolumn{6}{|c|}{ Test Value $=0$} \\
\hline & \multirow{2}{*}{$\mathrm{t}$} & \multirow{2}{*}{ df } & \multirow{2}{*}{ Sig. (2-tailed) } & \multirow{2}{*}{ Mean Difference } & \multicolumn{2}{|c|}{ 95\% Confidence Interval of the Difference } \\
\hline & & & & & Lower & Upper \\
\hline CAR TARGET $(-2,+2)$ & 7,871 & 85 & 000 & -13937105 & 10416368 & 17457841 \\
\hline CAR ACQUIRER $(-2,+2)$ &,- 548 & 84 & ,585 &,- 00315742 &,- 01461018 & ,00829535 \\
\hline
\end{tabular}

a. PERIODO PRE (0) POST (1) LEHMAN = 0, RANKING FIRST TIER (1) SECOND TIER (0) ADVISOR = 0 
Table A2.

\begin{tabular}{|c|c|c|c|c|c|c|}
\hline \multicolumn{7}{|c|}{ One-Sample Test ${ }^{\mathrm{a}}$} \\
\hline & \multicolumn{6}{|c|}{ Test Value $=0$} \\
\hline & \multirow{2}{*}{$\mathrm{t}$} & \multirow{2}{*}{ df } & \multirow{2}{*}{ Sig. (2-tailed) } & \multirow{2}{*}{ Mean Difference } & \multicolumn{2}{|c|}{$95 \%$ Confidence Interval of the Difference } \\
\hline & & & & & Lower & Upper \\
\hline CAR TARGET $(-2,+2)$ & 7,285 & 74 & 000 & 14471660 & , 10513366 & , 18429954 \\
\hline CAR ACQUIRER $(-2,+2)$ & ,602 & 75 & ,549 & ,00376588 &,- 00869805 & 01622981 \\
\hline
\end{tabular}

a. PERIODO PRE (0) POST (1) LEHMAN $=0$, RANKING FIRST TIER (1) SECOND TIER (0) ADVISOR $=1$

Table A3.

\begin{tabular}{|c|c|c|c|c|c|c|}
\hline \multicolumn{7}{|c|}{ One-Sample Test ${ }^{a}$} \\
\hline & \multicolumn{6}{|c|}{ Test Value $=0$} \\
\hline & \multirow{2}{*}{$\mathrm{t}$} & \multirow{2}{*}{$\mathrm{df}$} & \multirow{2}{*}{ Sig. (2-tailed) } & \multirow{2}{*}{ Mean Difference } & \multicolumn{2}{|c|}{$95 \%$ Confidence Interval of the Difference } \\
\hline & & & & & Lower & Upper \\
\hline CAR TARGET $(-2,+2)$ & 4,602 & 47 & , 000 & 12878323 & 07248531 & 18508115 \\
\hline CAR ACQUIRER $(-2,+2)$ & $-2,833$ & 38 & 007 & -02279384 & -03908364 & -00650404 \\
\hline
\end{tabular}

Table A4.

One-Sample Test ${ }^{\mathrm{a}}$

\begin{tabular}{|c|c|c|c|c|c|c|}
\hline & & & Test & alue $=0$ & & \\
\hline & & & & & $95 \%$ Confidence Inte & the Difference \\
\hline & & & & & Lower & Upper \\
\hline CAR TARGET $(-2,+2)$ & 5,180 & 19 & 000 & 25470290 & 15177807 & 35762773 \\
\hline CAR ACQUIRER $(-2,+2)$ & 0,662 & 28 & ,513 & , 006625272 &,- 01386418 & , 02711473 \\
\hline
\end{tabular}

a. PERIODO PRE (0) POST (1) LEHMAN = 1, RANKING FIRST TIER (1) SECOND TIER (0) ADVISOR = 1

Appendix 2. Correlation matrices: Target

Table B1. Coefficient correlations

\begin{tabular}{|l|c|c|c|c|c|c|c|c|c|c|}
\hline \multicolumn{1}{|c|}{ Model } & $\begin{array}{c}\text { Top vs } \\
\text { Not }\end{array}$ & Stock & $\begin{array}{c}\text { Same } \\
\text { Industry }\end{array}$ & $\begin{array}{c}\text { Deal } \\
\text { Value }\end{array}$ & Toehold & $\begin{array}{c}\text { Cross-Bor } \\
\text { der }\end{array}$ & $\begin{array}{c}\text { Relative } \\
\text { Size }\end{array}$ & $\begin{array}{c}\text { Tot } \\
\text { Advis.ors }\end{array}$ & Top-Tier & Cash \\
\hline Top vs Not & 1,000 &,- 108 &, 100 &, 139 &, 184 &, 035 &,- 013 &, 179 &,- 540 &,- 133 \\
\hline Stock &,- 108 & 1,000 &, 015 &, 032 &,- 212 &, 034 &,- 168 &, 075 &, 106 &, 714 \\
\hline Same Industry &, 100 &, 015 & 1,000 &, 067 &, 103 &, 035 &,- 083 &,- 104 &,- 118 &,- 008 \\
\hline Deal Value &, 139 &, 032 &, 067 & 1,000 &, 196 &,- 138 &,- 039 &,- 441 &,- 275 &, 029 \\
\hline Toehold &, 184 &,- 212 &, 103 &, 196 & 1,000 &,- 049 &, 046 &,- 134 &,- 216 &,- 196 \\
\hline Cross-Border &, 035 &, 034 &, 035 &,- 138 &,- 049 & 1,000 &, 111 &,- 001 &,- 117 &,- 059 \\
\hline Relative Size &,- 013 &,- 168 &,- 083 &,- 039 &, 046 &, 111 & 1,000 &,- 082 &, 028 &, 046 \\
\hline Tot Advisors &, 179 &, 075 &,- 104 &,- 441 &,- 134 &,- 001 &,- 082 & 1,0010 &,- 174 &, 071 \\
\hline Top-Tier &,- 540 &, 106 &,- 118 &,- 275 &,- 216 &,- 117 &, 028 &,- 174 & 1,000 &, 117 \\
\hline Cash &,- 133 &, 714 &,- 008 &, 029 &,- 196 &,- 059 &, 046 &, 071 &, 117 & 1,000 \\
\hline
\end{tabular}

PERIODO PRE (0) POST (1) LEHMAN = 0 / DEPENDENT VARIABLE: CAR TARGET $(-2,+2)$. 
Table B2. Coefficient correlations

\begin{tabular}{|c|c|c|c|c|c|c|c|c|c|c|}
\hline Model & Top vs Not & Stock & Toehold & $\begin{array}{l}\text { Deal } \\
\text { Value }\end{array}$ & $\begin{array}{c}\text { Same } \\
\text { Industry }\end{array}$ & $\begin{array}{c}\text { Cross-Bor } \\
\text { der }\end{array}$ & $\begin{array}{c}\text { Relative } \\
\text { Size }\end{array}$ & Tot Advisors & $\begin{array}{c}\text { Top-T } \\
\text { ier }\end{array}$ & Cash \\
\hline Top vs Not & 1,000 &,- 097 & , 070 & ,196 &,- 102 & , 114 &, 016 & ,254 &,- 540 &,- 073 \\
\hline Stock &,- 097 & 1,000 &,- 155 &,- 014 &,- 023 &,- 107 &,- 027 & ,101 & ,057 &, 779 \\
\hline Toehold & 070 &,- 155 & 1,000 &, 047 &,- 210 &,- 025 &,- 316 &,- 135 &,- 069 &,- 257 \\
\hline Deal Value & , 196 &,- 014 & ,047 & 1,000 &,- 058 &,- 070 &,- 001 &,- 031 &,- 441 &,- 038 \\
\hline Same Industry &,- 102 &,- 023 &,- 210 &,- 058 & 1,000 & 021 &, 254 & 074 &,- 047 &, 112 \\
\hline Cross-Border &, 114 &,- 107 &,- 025 &,- 070 & ,021 & 1,000 & ,037 &,- 188 &,- 156 &,- 144 \\
\hline Relative Size & ,016 &,- 027 &,- 316 &,- 001 & 254 & ,037 & 1,000 &, 124 & ,005 &, 144 \\
\hline Tot Advisors & ,254 &, 101 &,- 135 &,- 031 & 074 &,- 188 &, 124 & 1,000 &,- 372 & ,206 \\
\hline Top-Tier &,- 540 & ,057 &,- 069 &,- 441 &,- 047 &,- 156 & ,005 &,- 372 & 1,000 &,- 036 \\
\hline Cash &,- 073 &, 779 &,- 257 &,- 038 &, 112 &,- 144 & ,144 & ,206 &,- 036 & 1,000 \\
\hline
\end{tabular}

PERIODO PRE (0) POST (1) LEHMAN = 1 / DEPENDENT VARIABLE: CAR TARGET $(-2,+2)$.

\section{Appendix 3. Correlation matrices: Acquirer}

Table B3. Coefficient Correlations

\begin{tabular}{|l|c|c|c|c|c|c|c|c|c|c|}
\hline \multicolumn{1}{|c|}{ Model } & $\begin{array}{c}\text { Top vs } \\
\text { Not }\end{array}$ & Toehold & $\begin{array}{c}\text { Cross-Bor } \\
\text { der }\end{array}$ & $\begin{array}{c}\text { Same } \\
\text { Industry }\end{array}$ & Cash & Tot Advisors & $\begin{array}{c}\text { Relative } \\
\text { Size }\end{array}$ & $\begin{array}{c}\text { Deal } \\
\text { Value }\end{array}$ & Top-Tier & Stock \\
\hline Top vs Not & 1,000 &, 105 &, 103 &, 149 &,- 062 &, 119 &, 027 &, 214 &,- 539 &, 019 \\
\hline Toehold &, 105 & 1,000 &,- 049 &, 099 &,- 194 &,- 139 &, 046 &, 190 &,- 209 &,- 218 \\
\hline Cross-Border &, 103 &,- 049 & 1,000 &, 041 &,- 062 &, 004 &, 113 &,- 140 &,- 108 &, 033 \\
\hline Same Industry &, 149 &, 099 &, 041 & 1,000 &,- 005 &,- 103 &,- 078 &, 075 &,- 121 &, 022 \\
\hline Cash &,- 062 &,- 194 &,- 062 &,- 005 & 1,000 &, 073 &, 048 &, 028 &, 138 &, 712 \\
\hline Tot Advisors &, 119 &,- 139 &, 004 &,- 103 &, 073 & 1,000 &,- 082 &,- 439 &,- 198 &, 067 \\
\hline Relative Size &, 027 &, 046 &, 113 &,- 078 &, 048 &,- 082 & 1,000 &,- 033 &, 031 &,- 156 \\
\hline Deal Value &, 214 &, 190 &,- 140 &, 075 &, 028 &,- 439 &,- 033 & 1,000 &,- 248 &, 031 \\
\hline Top-Tier &,- 539 &,- 209 &,- 108 &,- 121 &, 138 &,- 198 &, 031 &,- 248 & 1,000 &, 168 \\
\hline Stock &, 019 &,- 218 &, 033 &, 022 &, 712 &, 067 &,- 156 &, 031 &, 168 & 1,000 \\
\hline
\end{tabular}

PERIODO PRE (0) POST (1) LEHMAN = 0 / DEPENDENT VARIABLE: CAR ACQUIRER $(-2,+2)$.

Table B4. Coefficient correlations

\begin{tabular}{|l|c|c|c|c|c|c|c|c|c|c|}
\hline \multicolumn{1}{|c|}{ Model } & $\begin{array}{c}\text { Top vs } \\
\text { Not }\end{array}$ & Toehold & Stock & Deal Value & $\begin{array}{c}\text { Same } \\
\text { Industry }\end{array}$ & Tot Advisors & $\begin{array}{c}\text { Cross-B } \\
\text { order }\end{array}$ & $\begin{array}{c}\text { Relative } \\
\text { Size }\end{array}$ & Cash & Top-Tier \\
\hline Top vs Not & 1,000 &, 060 &,- 033 &, 357 &, 035 &, 242 &, 043 &, 019 &, 025 &,- 666 \\
\hline Toehold &, 060 & 1,000 &,- 155 &, 055 &,- 210 &,- 121 &,- 016 &,- 318 &,- 256 &,- 080 \\
\hline Stock &,- 033 &,- 155 & 1,000 &,- 034 &,- 029 &, 069 &,- 129 &,- 020 &, 777 &, 107 \\
\hline Deal Value &, 357 &, 055 &,- 034 & 1,000 &,- 086 &, 002 &,- 032 &,- 004 &,- 058 &,- 430 \\
\hline Same Industry &, 035 &,- 210 &,- 029 &,- 086 & 1,000 &, 055 &, 005 &, 263 &, 097 &, 010 \\
\hline Tot Advisors &, 242 &,- 121 &, 069 &, 002 &, 055 & 1,000 &,- 091 &, 103 &, 189 &,- 452 \\
\hline Cross-Border &, 043 &,- 016 &,- 129 &,- 032 &, 005 &,- 091 & 1,000 &, 019 &,- 148 &,- 272 \\
\hline Relative Size &, 019 &,- 318 &,- 020 &,- 004 &, 263 &, 103 &, 019 & 1,000 &, 149 &, 027 \\
\hline Cash &, 025 &,- 256 &, 777 &,- 058 &, 097 &, 189 &,- 148 &, 149 & 1,000 &, 003 \\
\hline Top-Tier &,- 666 &,- 080 &, 107 &,- 430 &, 010 &,- 452 &,- 272 &, 027 &, 003 & 1,000 \\
\hline
\end{tabular}

PERIODO PRE (0) POST (1) LEHMAN = 1 / DEPENDENT VARIABLE: CAR ACQUIRER $(-2,+2)$ 
Appendix 4. Scatterplots of the residues: Target

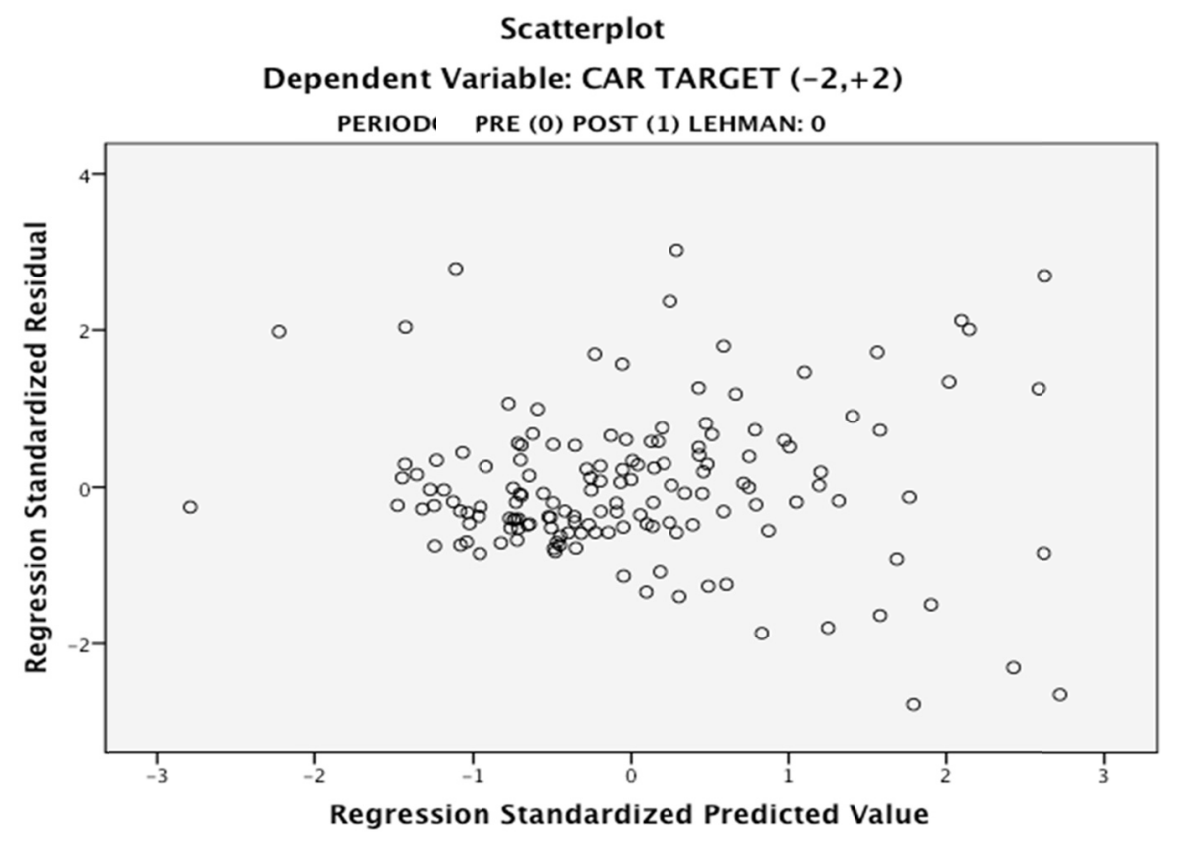

Figure C1.

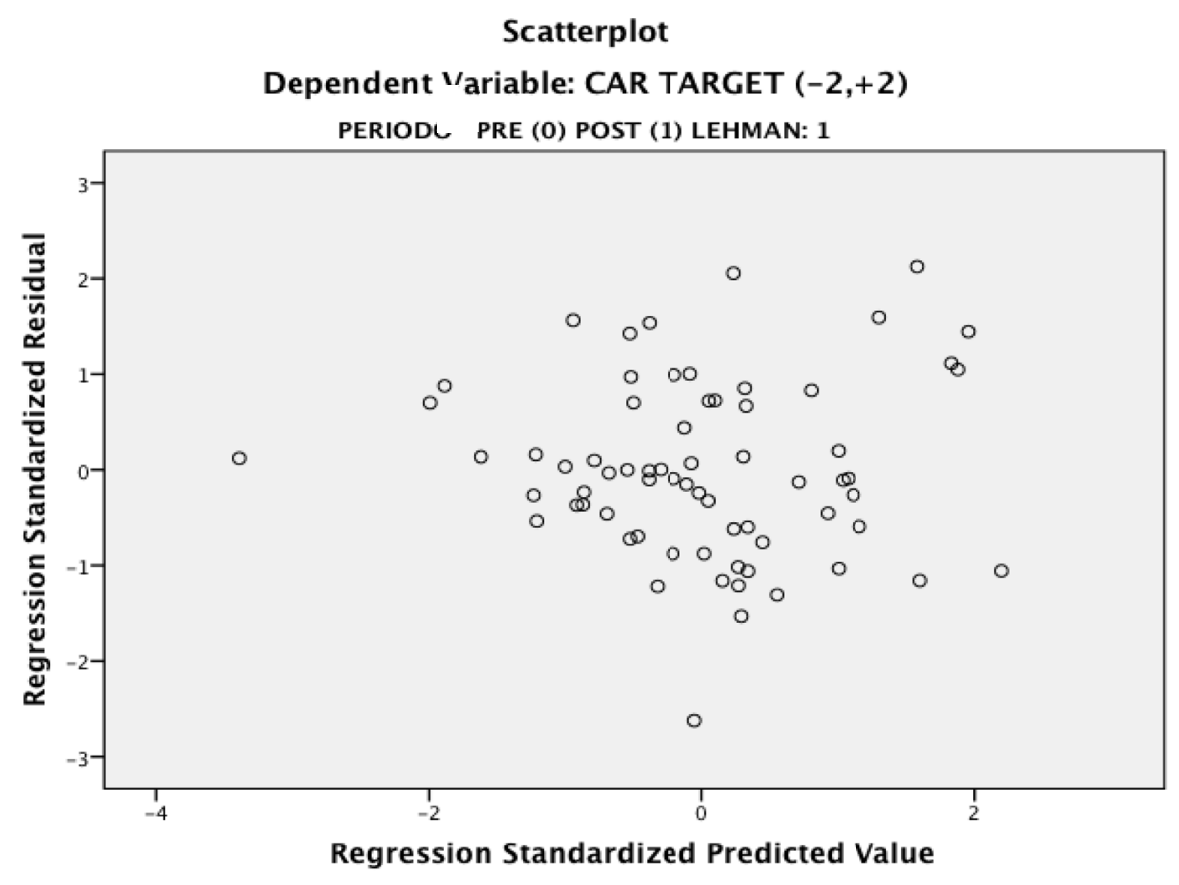

Figure C2. 
Appendix 5. Scatterplots of the residues: Acquirer

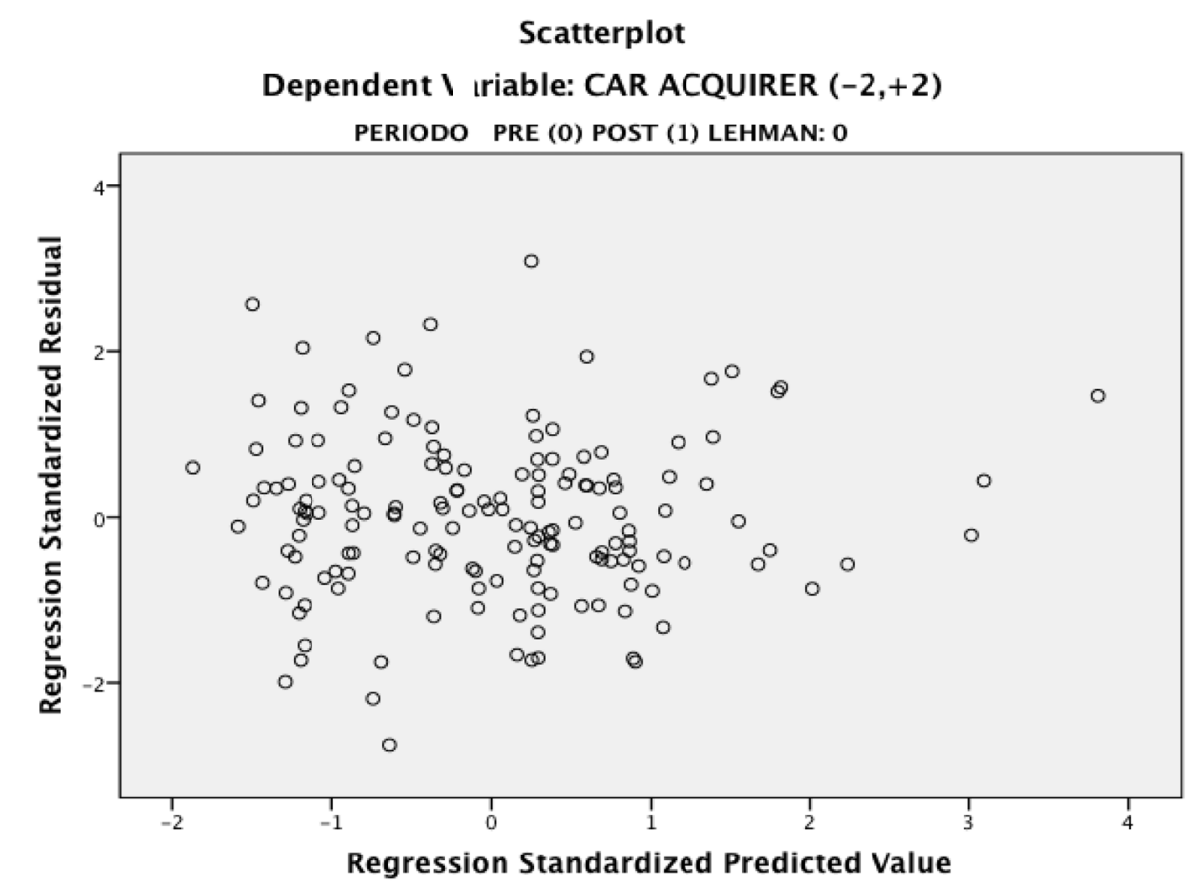

Figure C3.

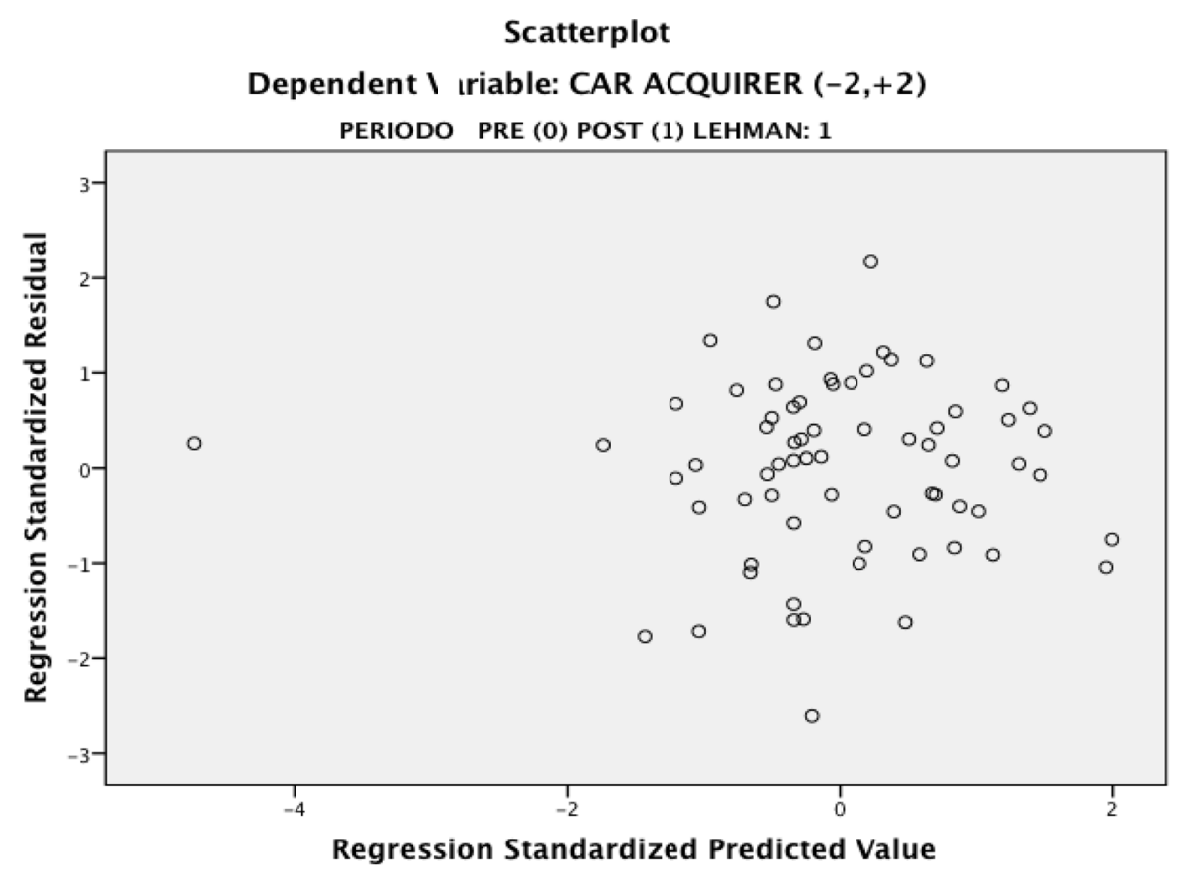

Figure C4. 


\section{Copyright Disclaimer}

Copyright for this article is retained by the author(s), with first publication rights granted to the journal.

This is an open-access article distributed under the terms and conditions of the Creative Commons Attribution license (http://creativecommons.org/licenses/by/3.0/). 